\title{
ネパール各地の伝統的住宅における夏季の温熱環境 \\ SUMMER THERMAL ENVIRONMENT IN TRADITIONAL VERNACULAR HOUSES IN SEVERAL AREAS OF NEPAL
}

\author{
リジャル ホムバハドゥル*，吉田治典**，梅宮典子*** \\ Hom Bahadur RIJAL, Harunori YOSHIDA and Noriko UMEMIYA
}

\begin{abstract}
For the purpose of evaluation and improvement of the thermal environment in traditional vernacular houses of the Banke, Bhaktapur, Dhading, Kaski and Solukhumbu districts of Nepal, the summer thermal indoor environment was measured and investigated in regards to: 1) the relationship between indoor and outdoor climate and 2) in comparison with existing studies.

The thermal environments of the houses investigated are as followings, 1) residents mitigated the thermal environment by moving in indoor, semi-open and outdoor spaces, 2) daytime indoor air temperature was 0.7 to $4.6 \mathrm{~K}$ less than the outdoor air temperature, 3) the thermal environment of the semi-open spaces was better than those of the indoor, 4) a cool radiation and air moisture control effect was found in houses with earthen floors, stone walls, brick walls and mud vessels, 5) the thermal environment of traditional houses was better than new type of houses, 6) much heat insulation was found in houses with grass, brick and wooden roofs , 7) a cool radiation effect was found in houses with grass, brick, stone, tile, cement and corrugated iron roofs, 8) the indoor and outdoor temperature difference was small in low altitude locations and large in high altitude locations, and 9) compared with existing studies, Nepalese and Japanese houses had comparable indoor and outdoor temperature differences in summer $(1.2 \mathrm{~K})$ and in winter $(2.2 \mathrm{~K})$.
\end{abstract}

\author{
Keywords: Nepal, Traditional vernacular houses, Earthen floor, \\ Surface temperature, Cool radiation, Regional difference \\ ネパール, 伝統的住宅, 土間, 表面温度, 冷放射, 地域差
}

\section{1. 序}

ネパールは, 面積は約 $147,181 \mathrm{~km}^{2}$ (北海道の約1.8倍)と小さいな がら, 標高は $60 \mathrm{~m} ら 8848 \mathrm{~m}$ に及び, 亜熱带から寒帯まで気候の 変化に富んだ国である。同じ気候带や民族, 宗教, 文化圈で類似し た伝統的住宅形式がみられ，気候風土と建築の関連性が認められる。 例えば,南部の亜熱帯地域では土間を持つ平屋の土壁造り住宅がみ られ, 中部温帯地域では, カトマンズ盆地に密集市街地に建つ4,5 階建て煉瓦造の町家がみられ,山岳地带に土間や半外部空間を持つ 2,3 階建て石造住宅, 棈円形平面の草莫き住宅がみられる。北部の ヒマラヤ地方の冷帯地域では斜面を活かしたシェルパ族の 2,3 階建 て石造住宅がある。建築環境工学の側面からみて,これらの伝統的 住宅には地域特性を活かした快適な温熱環境を得る次のような工夫 がみられる。例えば，1）日射を遮蔽する軒出や屋根形式，2)風通し の良い木造の開放的な半外部空間の利用，3)石，土, 草, 木などの 建材の熱特性を活かした構法,などである。人々は自然環境と共生し ながら，冷暖房設備を用いずに生活してきた。

近年,ネパールも近代化の影響をうけて近代的な生活が希求され， 効率や利便性が追求されるようになってきたが,解決すべき住宅環 境問題もある。具体的には，1)台所と寝室が分離されていないこと に起因する, 開放型いろりからの灰やすすによる寝具の污れ,2)調
理のための薪燃焼による発熱や発煙,3)伝統的建材の代替としての 工業建材の安易な使用 (トタン屋根など) に起因する室内温熱環境 の悪化，4)建築空間利用形態の変化 (上下階の独立化, 空のサイズ や位置の変化)への対応の遅れなどである。5)また, 最近では薪の 無計画な消費による森林資源の枯渴も問題視されてきており,エネ ルギー源である薪の適切な利用の検討も課題である。

さて, 既報りではネパールの山岳地帯の伝統的住宅について, 冬 季の内外温湿度差, 上下温度差などという,温熱環境の実態を明ら かにした。本報ではその結果を踏まえ,上記した,2)〜4)の問題に 焦点を絞り，既報で対象とした地域を含む,ネパールの気候を代表 する5つの地域の伝統的住宅について,夏季の室内外温熱環境や土 間・壁・屋根などの表面温度を測定し, 各地域の住宅の特色を明ら かにする。また，日本や中国の伝統的住宅に関する既往の研究で報 告されている内外温度差を本研究の結果と比較し相互の環境の類似 性について検討する。なお，上記5)の課題は次報により明らかにす る予定である。

\section{5 つの地域と調査対象住宅}

調査対象地域は亜熱帯気候 $(\mathrm{S})$ ) Banke 郡 $(\mathrm{A})$ ，温带気候( $(\mathrm{T})$ の Bhaktapur 郡(B), Dhading 郡(C), Kaski 郡(D) と冷帯気候(C)の
$*$ 京都大学大学院工学研究科環境地球工学専攻 博士課程·工修

** 京都大学大学院工学研究科環境地球工学専攻 教授・工博

****大阪市立大学大学院工学研究科都市系尃攻 講師・工博
Graduate Student, Dept. of Global Environment Eng. Faculty of Eng., Kyoto University, M. Eng.

Prof., Dept. of Global Environment Eng., Faculty of Eng., Kyoto University, Dr. Eng.

Lecturer, Dept. of Urban Engineering, Osaka City University, Dr. Eng. 

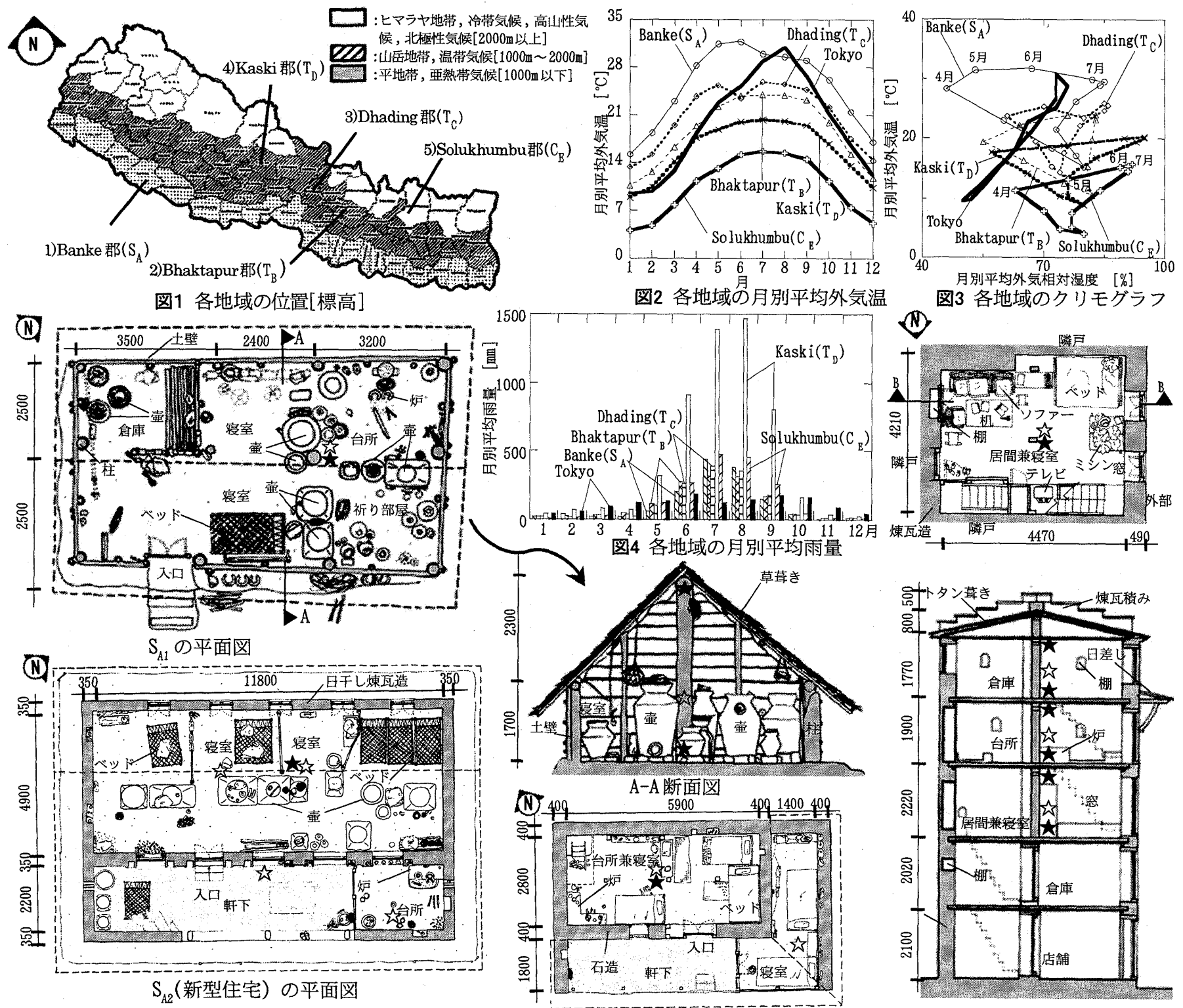

(a) $\mathrm{A}$ 郡の $\mathrm{S}_{\mathrm{A} 1}$ と $\mathrm{S}_{\mathrm{A} 2}$ の 1 階平面図, $A-A$ 断面図

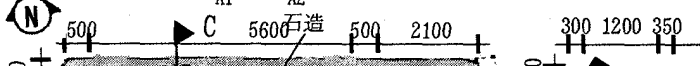
$\mathrm{T}_{\mathrm{D} 2}$ (新型住宅) の平面図

(b) $\mathrm{B}$ 郡の $\mathrm{T}_{\mathrm{B} 1}$ の 3 階平面図, B-B 断面図 $6400 \quad 3501200300 \quad$\begin{tabular}{lllllll}
450 & 3750 & 450 & 2700 & 450 & 3700 & 450 \\
\hline
\end{tabular}
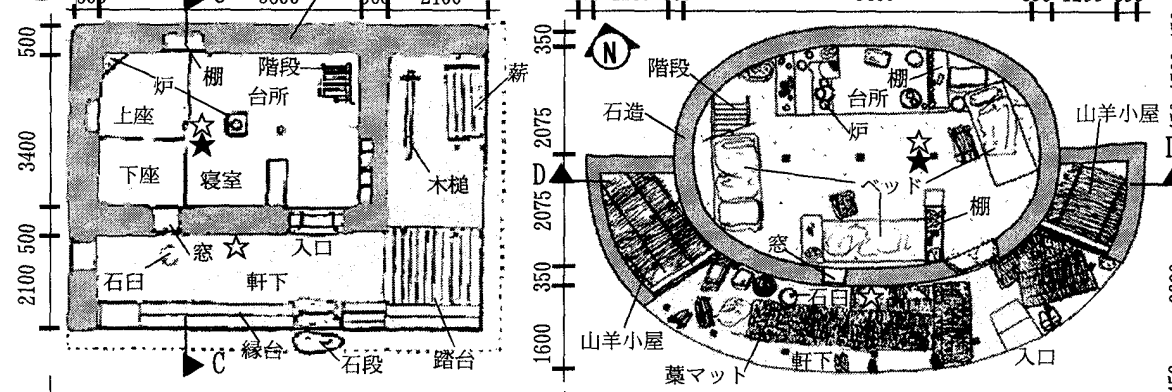

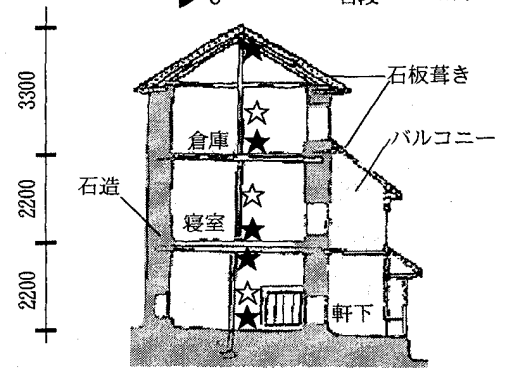

（c） C 郡の $\mathrm{T}_{\mathrm{c} 1}$ の 1 階平面図と C-C 断面図

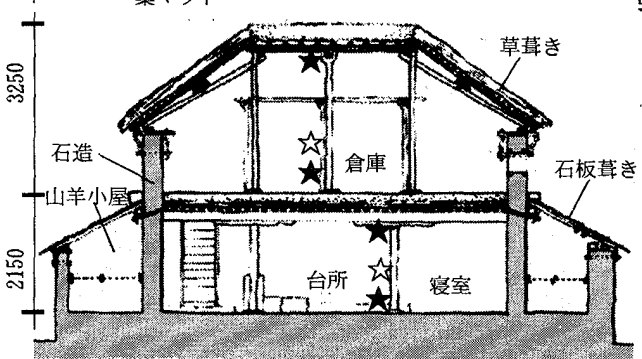

(d) $\mathrm{D}$ 郡の $\mathrm{T}_{\mathrm{D} 1}$ と $\mathrm{T}_{\mathrm{D} 2}$ の 1 階平面図， $\mathrm{D}-\mathrm{D}$ 断面図 図5 各地域の住宅の平面図と断面図 [公: 温湿度測定点, $\star$ : 温度測定点, $\square$ : 半外部空間, 単位: $\mathrm{mm}$ ]

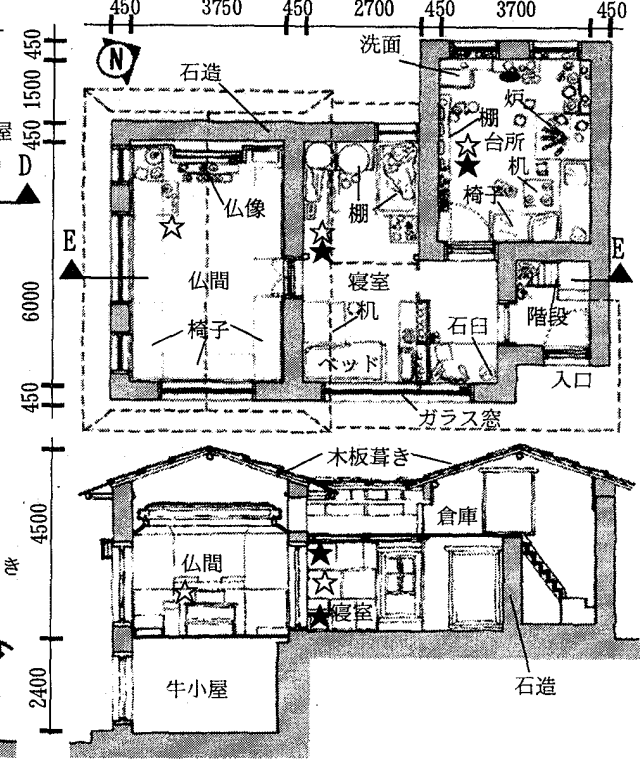

(e) $\mathrm{E}$ 郡の $\mathrm{S}_{\mathrm{v} 1}$ の 2 階平面図と $\mathrm{E}-\mathrm{E}$ 断面図 
表 1 各地域の概要

\begin{tabular}{|c|c|c|c|c|c|c|c|c|c|c|c|c|c|}
\hline 郡? & 所在地 & 湈发[m] & 気候区 & 地繁 & 5 月/1 月O $^{2} \mathrm{~T}_{\text {oul }}+$ & 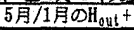 & 降水量 $[\mathrm{mm}]+$ & 锶泪地点 (気象台) & 宗教 & 民族 & 地区 & 生計 & 墱料 \\
\hline $\operatorname{Banke}\left(S_{A}\right)$ & ari $\overline{\mathrm{A}-1 \mathrm{M}}$ & $\doteqdot 150$ & 重慗带(S) & 平地 & $31.4 / 15.2$ & $53 / 80$ & 1391 & Nepaljung (Reg.off.) & バゥー, 土着 & nes & 震村 & 五炡，家㗜 & $\frac{1}{3 *}$ \\
\hline $\boldsymbol{r}\left(\mathrm{l}_{\mathrm{B}}^{\prime}\right)$ & 2 & $\fallingdotseq 1350$ & 温带(T) & 盆 & & $64 / 8$ & 13 & + & ウー, 仏教 & ワール & 都会 & 畺売，田畑 & 電気 \\
\hline$g\left(T_{0}\right)$ & 1 Sa & $\doteqdot 15$ & 温带(T) & 山岳地 & 3 & $70 / 76$ & 1460 & ibesi & ヒンドゥー & チェトリ & 農村 & 田畑, 家畜| & 薪* \\
\hline 4) 1 & -5 Sude村 & $\doteqdot 1700$ & 温带(T) & 山要 & & 75 & 53 & & ヒンドゥー & チェトリ & 蹍村 & 田姆, 家畜 & 萎* \\
\hline Soluk & lleri $\varangle-1$ Chiwang Khop & $\div 2600$ & 令带 $(\mathrm{C})$ & マラヤ゙ & $13.1 / 4.0$ & $76 / 80$ & 1718 & ialsa & 仏数 & & 噥村 & 田畑，家覴 & 薪* \\
\hline
\end{tabular}

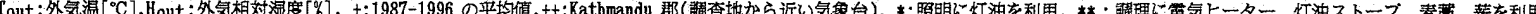

Solukhuumbu郡(E)(以下 $\mathrm{S}_{A}, \mathrm{~T}_{\mathrm{B}}, \mathrm{T}_{\mathrm{C}}, \mathrm{T}_{\mathrm{D}}, \mathrm{C}_{\mathrm{B}}$ と略)である。図 1 に位置と 気候区, 図 2 に月別平均外気温, 図 3 にクリモグラフ, 図 4 に月別平

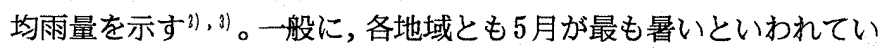
る。これは 6,7 月の平均外気温は高いが，6月から雨季となり，最高 気温が5月より低くなるので, 日較差も小さく, 暑さを感じないため と思われる。 $S_{A}(5$ 月)の外気温は東京(8月)と類似しているが, 内陸気 候であるため,相対湿度が東京より低く，日陰では涼しく感じられる。

表1に各地域の特質, 代表的な気象統計值 ${ }^{3)}$,生活習慣などを示す。 $\mathrm{S}_{\mathfrak{n}}, \mathrm{T}_{\mathfrak{l}}, \mathrm{T}_{\mathrm{B}}, \mathrm{C}_{\mathbb{g}}$ は農村であり, 田畑，家畜と薪(燃料)を基本とした自給 自足の生活が行なわれている。 $\mathrm{T}_{\mathrm{B}}$ は都市であり，商業従事者や勤め人 が多く,調理には主に電気，灯油を燃料としている。

図5に各地域の代表的注りな実測住宅の平面図と断面図を示す。表2 に実測住宅の概要を示す。住宅数」とは実測した全住宅数であり,節 4.2.11と4.3ではこの住宅数の内外温度差について考察する。「詳細 実測」住宅とは実測住宅中, 表面温度も測定した住宅であり,これに 関しては節4.2で様々な観点から詳細な分析を行う。

\subsection{Banke 郡 $\left(S_{A}\right)^{4)}$}

Mahadev村では切妻屋根の平屋が一般的である。図5(a)に $\mathrm{S}_{A 1}$ と $\mathrm{S}_{\mathrm{A} 2}$ の詳細実測住宅を示す $\left(S_{A 3}\right.$ と $S_{A 4}$ は省略)。 $S_{A 1}$ は草咠きで, 台所, 寝 室, 祈り部屋からなる。平屋であるため住宅平面が大きく, 天井高も 高く, 空間構成は開放的である。部屋はDeheri ${ }^{\text {注引) }}$ (款物を保存する巨 大壷, 以下単に螜と呼ぶ) と土壁の内壁で仕切られるが, 内壁の高さ は約 $1.8 \mathrm{~m}$ と低く, 内部は一室空間である。床は土間床である。外壁 は厚さ約 $10 \mathrm{~cm}$ の土壁注引であり，約 $1 \mathrm{~m}$ の高さに 2,3 個の直径約 $10 \mathrm{~cm}$ の穴を設け，採光する。壁は土の重さで徐々に低くなり，外壁上端と 屋根の間には $1 \mathrm{~m}$ 以上の隙間ができ,この隙間が探光や, 換気, 排煙の 役割を果たす。 $\mathrm{S}_{\mathrm{A} 2}$ は，厚さ約 $35 \mathrm{~cm}$ の日干し煉瓦造の粘土瓦咠きで， 最近 4,5 年来流行の新型住宅である。内部は $\mathrm{S}_{\mathrm{A} 1}$ と同様であるが, 壁 に開閉可能な空を設け, 軒下があり, 台所はその一部にある。 $S_{A 3}$ は 木柱だけで壁の無い開放的な草咠きで, 作業場, 畜舎である。 $\mathrm{S}_{\mathrm{A4}}$ は 日干し煉瓦造のセメント瓦咠きで,寝室と祈り部屋である。

\subsection{Bhaktapur 郡 $\left(T_{B}\right)^{5)}$}

いる。壁は厚さ約

表 2 各地域の実測住宅の概要

$50 \mathrm{~cm}$ の石造注4)で, 内外から粘土モル タルを塗って仕上 げる。㥶は木製で， 透かし彫り空,戸な し空, 戸付き空の 3 種類がある。半外部 空間として 1 階の

\begin{tabular}{|c|c|c|c|c|c|c|}
\hline 郡名 & $\begin{array}{l}\text { 住宅 } \\
\text { 数 }\end{array}$ & 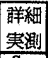 & 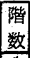 & $\begin{array}{l}\text { 壁体 } \\
\text { 構造 } \\
\end{array}$ & $\begin{array}{c}\text { 屋根形式, } \\
\text { 尿根材 }\end{array}$ & \begin{tabular}{|c|} 
世带 \\
人数
\end{tabular} \\
\hline \multirow{3}{*}{ 1)Banke $\left(S_{\AA}\right)$} & \multirow{3}{*}{10} & $S_{h 1}$ & 1 & 土型 & 切麦,草 & 3 \\
\hline & & $\begin{array}{l}S_{A 2} \\
S_{13}\end{array}$ & $\begin{array}{l}1 \\
1\end{array}$ & 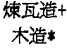 & $\begin{array}{l}\text { 切麦,粘土瓦 } \\
\text { 切妻,草 }\end{array}$ & \\
\hline & & $S_{A_{1}}$ & 1 & 棟瓦造十 & 切妻,セメント瓦 & \\
\hline \multirow[t]{2}{*}{ 2)Bhaktapur( $\left.1_{B}\right)$} & \multirow[t]{2}{*}{5} & $T_{B 1}$ & $\begin{array}{l}5 \\
4\end{array}$ & 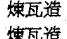 & 切青,トタン & $\begin{array}{l}4 \\
5\end{array}$ \\
\hline & & $T_{B 2}$ & 4 & 娻瓦造 & 陸屋根, 煉瓦 & 5 \\
\hline \multirow{3}{*}{ 3)Dhading ( $\mathrm{I}_{6}$ ) } & \multirow{3}{*}{8} & $T_{61}$ & 3 & 石遭 & 入每屋,石板 & 11 \\
\hline & & $\mathrm{T}_{\mathrm{cl}}$ & 2 & 石造 & 入母屋,トタン & - \\
\hline & & $\mathrm{T}_{\mathrm{c3}}$ & 2 & 石造 & 入母屋,草 & 8 \\
\hline \multirow[t]{2}{*}{ 4) Raski( TD) } & \multirow[t]{2}{*}{7} & $T_{01}$ & 2 & 石造 & 入乎屋,草 & 5 \\
\hline & & $T_{D_{2}}$ & 2 & 石造 & 入母屋，石板 & 5 \\
\hline 5) Solukhumbu( $\left.C_{B}\right)$ & 6 & $\mathrm{C}_{\mathrm{B} 1}$ & 3 & 石透 & 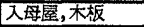 & 6 \\
\hline
\end{tabular}
軒下, 2 階のバルコニーとバルコニ一部屋がある。 $\mathrm{T}_{\mathrm{c} 2}$ はト夕ン咠き で 2 階が寝室, $\mathrm{T}_{c 3}$ は草苗きで, 2 階が寝室兼倉庫である。 2.4 Kaski 郡 $\left(T_{D}\right)^{7) .8)}$

Sude村では2 階建ての各階 1 室空間形式の住宅が一般的である。 20年ほど前までは楕円形平面の住宅が一般的であった。棈円形住宅 を作ると幸福になると信じられており，また壁に積み重ねる石の形 が自由で,矩形平面の壁のように石を刻んで角を合わせる必要がな く施工が楽なので普及してきた。しかし調査時には棈円形住宅は近 郊の村も含めて2戸しか残存しなかった。草咠き屋根の材料確保が 困難になり，石板やトタンが屋根の形に合わず, 家具も置きにくい ことなどが原因である。図5(d)に $\mathrm{T}_{\mathrm{D} 1}$ と $\mathrm{T}_{\mathrm{D} 2}$ の詳細害測住宅を示す。 $\mathrm{T}_{\mathrm{D} 1}$ は棈円形平面の伝統的草莫き住宅で, 1 階が台所兼寝室, 2 階が 穀物保存倉庫である。 $\mathrm{T}_{\mathrm{D} 2}$ の新型住宅は矩形平面を持つ石板咠きで， 1 階は寝室 (軒下), 台所兼寝室, 2 階が倉庫である。床, 壁, 空構 法はともにDhading郡と同様である。

2.5 Solukhumbu 郡( $\left.\mathrm{C}_{E}\right)^{9)}$

Chiwang Khop村では斜面を断面計画に活かした 2,3階建て住宅 が典型的である。住宅の規模は大きく,室内は目的別に仕切られる。 図5(e)に $\mathrm{C}_{\mathrm{B} 1}$ の詳細実測住宅を示す。 $\mathrm{C}_{\mathrm{B} 1}$ は木板苜きで, 1 階が畜舎, 2 階が仏間 (Gumba), 寝室と台所兼居間, 3 階が倉庫と寝室である。 仏間は寝室としても利用される。林は1階が土間床, 2,3 階が木板張 りである。壁は厚さ約 $50 \mathrm{~cm}$ の石造で, ガラス空が設けられている。

\section{3. 測定概要}

\section{1 測定日時}

測定は 2000 年 4 〜月の夏季の代表的な時期に各地域で 5 日間ず つ行った。分析日として, 測定期間中の晴天日をそれぞれ 1 日選定 した。これらの外気温(表4)は,気象台(表1)の月別平均外気温に近 いことから,夏季の代表的な天候と考えられる。日時は表4に示す。

\section{2 測定項目, 測定位置, 測定方法}

表 3 に測定項目と使用機器を示す。測定項目は, 外部環境として 温湿度, 日射量, 風向風速, 内部環境として温湿度, グローブ温度 とした。日射量, 風向風速, 外気温は, 建物から $25 \mathrm{~m}$ 離れた障害物

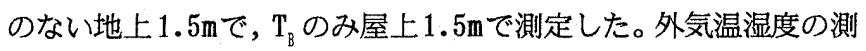
定にあたっては,日射の影響を避ける工夫をした。

測定位置は図 5 に示す。室内温湿度は, 各室ほほ中央の床上 $0.1 \mathrm{~m}$, 床上 $0.6 \mathrm{~m}$, 天井下 $0.1 \mathrm{~m}$, 屋根裏下 $0.1 \mathrm{~m}$ (以下, 屋根裏付近と略) と 存倉庫である。床は 1 階が土間床, 2,3 階が木板の上を粘土で固めて 
表3 測定概要と使用機器

\begin{tabular}{|c|c|c|c|}
\hline 空間 & 涀定項目 & 泪定位置 $[\mathrm{m}]$ & 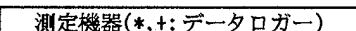 \\
\hline \multirow{4}{*}{ 外部 } & 日射量 & & 日射訲 H-205(横河電子機器)* \\
\hline & & & 風速部 A-702（横河電子機器）* \\
\hline & & 地上 $1.5^{\times}$ & 風向計 A-802（横河電子機器）* \\
\hline & $\begin{array}{l}\text { 外気温 } \\
\text { 外気湿度 }\end{array}$ & & $T$ 型極細熱伝対, 直径 $0.08 \mathrm{~mm} *$ \\
\hline \multirow{5}{*}{ 半外部 } & 室内温湿度 & 50.6 & 携带型温度計 TR-71 (T \&D) \\
\hline & 床付近気温 & 上0. & 携带型温湿度計 TR-72（T＆D) \\
\hline & 天井付近気温 & 天井下 0.1 & 缸带型温湿度計 TR-72（T \&D) \\
\hline & 表面温度 & 央部 & T 型極細熱伝対, 直径 $0.08 \mathrm{~mm}$ \\
\hline & $\begin{array}{l}\text { グローブ温度 } \\
\text { 室内国呠 }\end{array}$ & 床上 0.6 & グローブ温度計, 直径 $15 \mathrm{~cm}$ (柴田)+ \\
\hline & & & 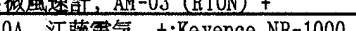 \\
\hline
\end{tabular}

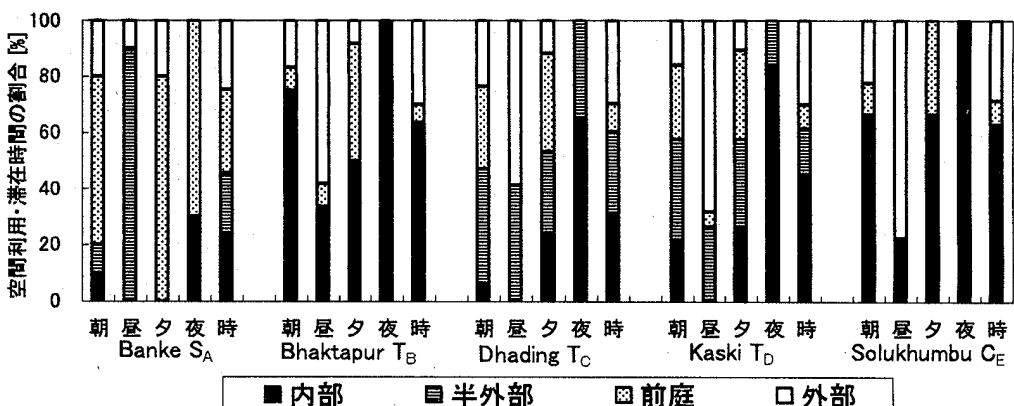

表4 各地域の住宅空間における日平均気温, 表面温度, 相対湿度と絶対湿度 図 6 各地域の滞在場所・滞在時間の割合

\begin{tabular}{|c|c|c|c|c|c|c|c|c|c|c|c|c|c|c|c|c|c|c|}
\hline \multirow{2}{*}{\begin{tabular}{|c|} 
韵查郡名 \\
分析日(2000 年)
\end{tabular}} & \multirow{2}{*}{$\begin{array}{l}\text { 住 } \\
\text { 宅 } \\
\text { 名 }\end{array}$} & \multirow[b]{2}{*}{ 空間名 } & \multirow[b]{2}{*}{ 測定階 } & \multicolumn{6}{|c|}{ 平均気温 $\left[{ }^{\circ} \mathrm{C}, \mathrm{K}\right]$} & \multicolumn{5}{|c|}{ 床衰面温度 $\mathrm{T}_{\mathrm{Sf}}$ 壁表面温度 $\mathrm{T}_{\mathrm{SW}}$} & \multicolumn{2}{|c|}{ 相対湿度 } & \multicolumn{2}{|c|}{ 絶対湿度 } \\
\hline & & & & \multicolumn{3}{|c|}{$\begin{array}{l}\text { 外気温 } \mathrm{T}_{\text {out }} \\
\text { 室温 } \mathrm{T} \text { in }{ }^{\circ} \mathrm{C} C\end{array}$} & \multicolumn{3}{|c|}{ 丙外温度差 } & \begin{tabular}{|l|}
$T_{\text {sf }}$ \\
{$\left[{ }^{\circ} \mathrm{C}\right]$} \\
$\left.{ }^{\circ}\right]$ \\
\end{tabular} & $\begin{array}{c}\mathrm{T}_{\mathrm{sf}} \mathrm{T}^{-\mathrm{T}} \mathrm{in} \\
{[\mathrm{K}]}\end{array}$ & 測 & \begin{tabular}{|c|}
$\mathrm{T}_{\mathrm{SW}}$ \\
{$\left[{ }^{\circ} \mathrm{C}\right]$} \\
$\left.{ }^{\mathrm{C}}\right]$ \\
\end{tabular} & $\begin{array}{c}\mathrm{T}_{\mathbf{s W}}-\mathrm{T}_{\mathrm{in}} \\
{[\mathrm{K}]}\end{array}$ & 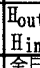 & $\begin{array}{l}\mathrm{H}_{\text {in- }} \\
\text { Hout } \\
\text { Hout }\end{array}$ & \begin{tabular}{|r|}
$X_{\text {out, }}$ \\
$X_{\text {in }}$ \\
\end{tabular} & \begin{tabular}{|l|}
$\mathrm{X}_{\text {in }}$ \\
$\mathrm{X}_{\text {out }}$ \\
\end{tabular} \\
\hline 1) Banke $\left(S_{A}\right)$ & 外部T & out, $D_{\text {ou }}$ & , $\bar{X}_{\text {out }}{ }^{2}$ & $\overline{32.4}$ & 36.6 & 28.8 & & & & & & & & & 52 & & 15.1 & \\
\hline & $\mathrm{S}_{\mathrm{AL}}$ & 部幄 & $1 \mathrm{~F}$ & 31.5 & 32.1 & 30.8 & -0.9 & -4.5 & 2.0 & 29.1 & -2.4 & $\overline{\mathrm{S}}$ & 33.2 & 1.7 & 51 & -1 & 15.0 & -0.1 \\
\hline $\begin{array}{l}\text { 分析日:5月10日 } \\
\text { 认: 附属屋の值 }\end{array}$ & $\$_{A 2}$ & 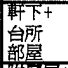 & $\begin{array}{l}1 \mathrm{~F} \\
1 \mathrm{~F} \\
1 \mathrm{~F}\end{array}$ & $\begin{array}{l}31.9 \\
35.3 \\
31.1 \\
\end{array}$ & $\begin{array}{l}33.7 \\
37.7 \\
32.0 \\
\end{array}$ & $\begin{array}{l}30.1 \\
33.0 \\
30.1 \\
\end{array}$ & $\begin{array}{r}-0.5 \\
3.8 \\
-1.3 \\
\end{array}$ & $\begin{array}{r}-2.9 \\
5.6 \\
-4.6 \\
\end{array}$ & $\begin{array}{l}1.3 \\
2.2 \\
1.3 \\
\end{array}$ & 30.6 & -0.5 & $s$ & 32.8 & 1.7 & $\begin{array}{l}50 \\
53 \\
\end{array}$ & $\begin{array}{l}-2 \\
1 \\
\end{array}$ & $\begin{array}{l}14.9 \\
15.2 \\
\end{array}$ & -0.2 \\
\hline & $S_{\Delta 8}$ & 附属屋 & $\mathrm{IF}$ & 31.8 & 34.0 & 29.5 & -0.6 & -2.6 & 0.7 & & & & & & & & & \\
\hline 2) Bhaktapur('('B) & 外部门 & out,, $\mathrm{D}_{\text {oul }}$ & , $X_{\text {out }}$ & 22.4 & 23.8 & 21.1 & & & & & & & & & 74 & & 14.6 & \\
\hline 分析日:5月24日 & $\mathrm{T}_{\mathrm{BS}}$ & 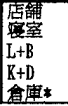 & $\begin{array}{l}1 \mathrm{~T} \\
2 \mathrm{~F} \\
3 \mathrm{~F} \\
4 \mathrm{~F} \\
5 \mathrm{~F} \\
\end{array}$ & $\begin{array}{l}23.2 \\
23.2 \\
24.3 \\
24.4 \\
24.2\end{array}$ & $\begin{array}{l}23.1 \\
23.1 \\
24.6 \\
24.7 \\
24.6\end{array}$ & $\begin{array}{l}23.3 \\
23.3 \\
24.1 \\
24.1 \\
23.8 \\
\end{array}$ & $\begin{array}{l}0.8 \\
0.8 \\
1.9 \\
2.0 \\
1.8 \\
\end{array}$ & $\begin{array}{r}-0.7 \\
-0.7 \\
0.8 \\
0.9 \\
0.8 \\
\end{array}$ & $\begin{array}{l}2.2 \\
2.2 \\
3.0 \\
3.0 \\
2.7 \\
\end{array}$ & $\begin{array}{l}26.0 \\
28.2 \\
25.5 \\
\end{array}$ & $\begin{array}{l}1.7 \\
3.8 \\
1.3 \\
\end{array}$ & $\begin{array}{l}\text { W } \\
\text { N } \\
\text { S }\end{array}$ & $\begin{array}{l}25.3 \\
25.0 \\
25.3\end{array}$ & $\begin{array}{l}1.0 \\
0.6 \\
1.1\end{array}$ & $\begin{array}{l}73 \\
69 \\
69 \\
70 \\
\end{array}$ & $\begin{array}{l}-1 \\
-5 \\
-5 \\
-4\end{array}$ & \begin{tabular}{|l|}
15.2 \\
15.1 \\
15.4 \\
15.3
\end{tabular} & $\begin{array}{l}0.6 \\
0.5 \\
0.8 \\
0.7\end{array}$ \\
\hline 3)Dhading(TC) & 外部T & out, $D_{\mathrm{ou}}$ & $\mathrm{X}_{\text {out }}{ }^{2}$ & 20.1 & 21.9 & 18.4 & & & & & & & & & 66 & & 12.0 & \\
\hline $\begin{array}{l}\text { 分析日:4月22日 } \\
\text { B:バルコニ二部屋 } \\
\text { 它:軒下の值 }\end{array}$ & $\mathrm{T}_{\mathrm{CI}}$ & 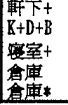 & $\begin{array}{c}1 \mathrm{~F} \\
1 \mathrm{~F} \\
2 \mathrm{~F} B \\
2 \overline{\mathrm{F}} \\
3 \mathrm{~F} \\
\end{array}$ & $\begin{array}{l}20.9 \\
28.8 \\
21.1 \\
24.2 \\
21.9 \\
\end{array}$ & $\begin{array}{l}22.3 \\
29.9 \\
22.3 \\
24.6 \\
23.2 \\
\end{array}$ & $\begin{array}{l}19.5 \\
27.7 \\
19.9 \\
23.7 \\
20.6 \\
\end{array}$ & $\begin{array}{l}0.8 \\
8.7 \\
1.0 \\
4.1 \\
1.8 \\
\end{array}$ & $\begin{array}{l}0.4 \\
8.0 \\
0.4 \\
2.7 \\
1.3 \\
\end{array}$ & $\begin{array}{l}1.1 \\
9.3 \\
1.5 \\
5.3 \\
2.2 \\
\end{array}$ & $\begin{array}{l}25.5 \\
23.7 \\
\end{array}$ & $\begin{array}{l}1.3 \\
1.8 \\
\end{array}$ & $\begin{array}{l}\mathrm{E} \\
\mathrm{N} \\
\mathrm{N}\end{array}$ & $\begin{array}{l}26.0 \\
24.5 \\
22.6\end{array}$ & $\begin{array}{l}0.3 \\
0.7\end{array}$ & $\begin{array}{l}44 \\
65 \\
55 \\
62 \\
\end{array}$ & $\begin{array}{l}-22 \\
-1 \\
-11 \\
-4\end{array}$ & $\begin{array}{l}12.6 \\
12.1 \\
12.4 \\
12.0\end{array}$ & $\begin{array}{l}0.6 \\
0.1 \\
0.4 \\
0.0\end{array}$ \\
\hline 4) Kaski(TD) & 外部T & out, $\mathrm{D}_{\text {ou }}$ &,$X_{\text {out }}$ & 19.5 & 21.7 & 17.2 & & & & & & & & & 63 & & 11.0 & \\
\hline $\begin{array}{l}\text { 分析日:4月30日 } \\
\text { 论:軒下の值 }\end{array}$ & $T_{01}$ & 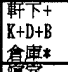 & $\begin{array}{l}1 \mathrm{lr} \\
1 \mathrm{~F} \\
2 \mathrm{~F} \\
\end{array}$ & $\begin{array}{l}19.9 \\
21.6 \\
20.3 \\
\end{array}$ & $\begin{array}{l}21.4 \\
21.8 \\
20.9 \\
\end{array}$ & $\begin{array}{l}18.5 \\
21.5 \\
19.8 \\
\end{array}$ & $\begin{array}{l}0.4 \\
2.1 \\
0.8 \\
\end{array}$ & $\begin{array}{r}-0.3 \\
0.1 \\
-0.8 \\
\end{array}$ & $\begin{array}{r}1.3 \\
4.3 \\
2.6 \\
\end{array}$ & $\begin{array}{l}21.0 \\
21.3 \\
\end{array}$ & $\begin{array}{r}-0.6 \\
1.0 \\
\end{array}$ & & 21.1 & $\begin{array}{r}-0.2 \\
0.8 \\
\end{array}$ & $\begin{array}{l}59 \\
60 \\
\end{array}$ & $\begin{array}{l}-4 \\
-3 \\
\end{array}$ & $\begin{array}{l}11.7 \\
11.0\end{array}$ & $\begin{array}{l}0.7 \\
0.0 \\
\end{array}$ \\
\hline & $\mathrm{T}_{D 2}$ & 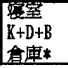 & $\begin{array}{l}7 \mathrm{~T} \\
1 \mathrm{~F} \\
2 \mathrm{~F}\end{array}$ & $\begin{array}{l}20.6 \\
20.5 \\
20.7 \\
\end{array}$ & $\begin{array}{l}21.6 \\
21.0 \\
20.9 \\
\end{array}$ & $\begin{array}{l}19.7 \\
20.0 \\
20.6 \\
\end{array}$ & $\begin{array}{l}1.1 \\
1.0 \\
1.2 \\
\end{array}$ & $\begin{array}{l}-0.1 \\
-0.7 \\
-0.8 \\
\end{array}$ & $\begin{array}{l}2.5 \\
2.8 \\
3.4 \\
\end{array}$ & 19.1 & -1.4 & $\begin{array}{l}E \\
W \\
\end{array}$ & $\begin{array}{r}21.8 \\
22.2 \\
\end{array}$ & $\begin{array}{l}1.3 \\
1.5 \\
\end{array}$ & $\begin{array}{l}60 \\
61 \\
60 \\
\end{array}$ & $\begin{array}{l}-3 \\
-2 \\
-3 \\
\end{array}$ & $\begin{array}{l}11.0 \\
11.1 \\
11.1 \\
\end{array}$ & $\begin{array}{l}0.0 \\
0.1 \\
0.1\end{array}$ \\
\hline 5) Solukhumbu( $\left.\mathrm{C}_{\mathrm{E}}\right)$ & 外部? & out, $D_{\text {ou }}$ & , $\mathrm{X}_{\text {out }}$ & 15.5 & 17.3 & 13.7 & & & & & & & & & 88 & & 13.3 & \\
\hline 分析日:5月17日 & $T_{\mathrm{p} 1}$ & 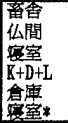 & $\begin{array}{l}1 \mathrm{~F} \\
2 \mathrm{~F} \\
2 \mathrm{~F} \\
2 \mathrm{~F} \\
3 \mathrm{~F} \\
3 \mathrm{~F}\end{array}$ & $\begin{array}{c}16.6 \\
18.7 \\
18.1 \\
19.7 \\
20.1 \\
17.5\end{array}$ & $\begin{array}{c}16.6 \\
18.8 \\
18.2 \\
19.7 \\
21.0 \\
17.9\end{array}$ & $\begin{array}{c}16.5 \\
18.7 \\
18.0 \\
19.8 \\
19.3 \\
17.1\end{array}$ & $\begin{array}{l}1.1 \\
3.2 \\
2.6 \\
4.2 \\
4.6 \\
2.0\end{array}$ & $\begin{array}{c}-0.7 \\
1.5 \\
0.9 \\
2.4 \\
3.7 \\
0.6\end{array}$ & $\begin{array}{l}2.8 \\
5.0 \\
4.3 \\
6.1 \\
5.6 \\
3.4\end{array}$ & $\begin{array}{l}19.6 \\
19.9 \\
23.3\end{array}$ & $\begin{array}{l}0.9 \\
0.2 \\
3.2\end{array}$ & $\begin{array}{l}S \\
W \\
S\end{array}$ & $\begin{array}{l}19.6 \\
18.9 \\
20.9\end{array}$ & $\begin{array}{l}0.9 \\
-0.8 \\
0.8\end{array}$ & $\begin{array}{l}69 \\
65 \\
77\end{array}$ & $\begin{array}{l}-1 \\
-17 \\
-14 \\
-19 \\
-23 \\
-11\end{array}$ & $\begin{array}{l}14.1 \\
13.2 \\
13.3 \\
13.6 \\
13.1 \\
13.3\end{array}$ & $\begin{array}{c}0.8 \\
-0.1 \\
0.0 \\
0.3 \\
-0.2 \\
0.0\end{array}$ \\
\hline
\end{tabular}

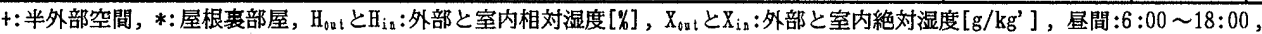
夜間:0:00 6:00 と18:00 24:00, L:Living, B:Bed, $\mathbb{K}:$ kitchen, D:Dining, N:North, S: South, E:East, W:West

日射が強い11〜 16時を「㡺」, 日射が弱い17〜19時を「夕」, 就寝する20〜翌日4時を「夜」 とした。図中の「朝」昼」タ」 「夜」はそれぞれの時間帯で各 場所に滞在する人数の全人数 に対する割合「時」はそれぞ れの場所に滞在する時間の 24 時間に対する割合である。

居住者の滞在場所と滞在時 間の傾向は, (1) $\mathrm{S}_{\mathrm{A}}$, (2) $\mathrm{T}_{B}, \mathrm{C}_{B}$, (3) $\mathrm{T}_{c}, \mathrm{~T}_{2}$ の3つに分類できる。 (1)と(3)では朝・夕は前庭に， 㡺は半外部に滞在し, 夜は(1) では前庭に,(3)では内部や半 外部に滞在する。

具体的に説明すると， $S_{\AA}$ で は㡺間はベッド用のひもや木

した。グローブ温度と室内風速は床上 $0.6 \mathrm{~m} て ゙$ 測定した。表面温度 は床，壁，屋根の表面に熱電対を薄いテープで貼って測定した。測 定值は5 分間隔で記録し,風向以外は変動の緩やかなデー夕を得る ためローパスフィルターで処理した。住まい方の把握のため, $\mathrm{S}_{\mathrm{A}} 10$ 人, $\mathrm{T}_{\mathrm{B}} 12$ 人, $\mathrm{T}_{\mathrm{C}} 17$ 人, $\mathrm{T}_{\mathrm{D}} 19$ 人, $\mathrm{C}_{\mathrm{B}} 9$ 人に聴き取り調查を行った。

\section{4. 結果と考察}

図7に各地域の住宅における温熱環境の時刻変化を,表 4 に各空 間の外気温, 内外温度差, 表面温度, 湿度の時間平均值を示す。

\section{1 各地域の気象条件}

各地域の最大日射量は $713\left(\mathrm{C}_{\mathrm{B}}\right) \sim 846 \mathrm{~W} / \mathrm{m}^{2}\left(\mathrm{~T}_{\mathrm{c}}\right)$ であった。日平均 風速は外部で $0.3\left(\mathrm{~S}_{\mathrm{A}}\right) \sim 0.8 \mathrm{~m} / \mathrm{s}\left(\mathrm{T}_{\mathrm{B}}, \mathrm{T}_{\mathrm{f}}\right)$, 室内で $0.1\left(\mathrm{~T}_{\mathrm{B}}, \mathrm{C}_{\mathrm{B}}\right) \sim 0.4 \mathrm{~m} /$ $s\left(T_{c}\right)$ であった。各地域の日平均外気温と相対湿度は $15.5\left(C_{\mathbb{B}}\right) \sim$ $32.4^{\circ} \mathrm{C}\left(\mathrm{S}_{\mathrm{A}}\right)$ と $52\left(\mathrm{~S}_{\mathrm{A}}\right) \sim 88 \%\left(\mathrm{C}_{\mathrm{B}}\right)$ の範囲にあり，最大 $16.9 \mathrm{~K}$ と， $36 \%$ の地域による差がある。日平均室温は $17.5\left(\mathrm{C}_{\mathrm{B}}\right) \sim 35.3^{\circ} \mathrm{C}\left(\mathrm{S}_{\mathrm{A}}\right)$ の範 囲にあり,最大 $17.8 \mathrm{~K}$ の地域による差がある。日平均グローブ温度 は20.7 $\left(\mathrm{C}_{\mathrm{B}}\right) \sim 33.0^{\circ} \mathrm{C}\left(\mathrm{S}_{\mathrm{A}}\right)$ で, $\mathrm{T}_{\mathrm{c}}$ では室温よりも0.5K 低く, $\mathrm{S}_{\mathrm{A}}$ では 室温よりも $1.9 \mathrm{~K}$ 高い。

\section{2 各地域の比較}

\subsection{1 移動による温熱環境の緩和}

図6に各地域の滞在場所と滞在時間の割合を示す。軒下, バルコ ニ一は「半外部」, 庭, 畜舎, 路地, 広場, 屋上テラスは「前庭」, 畑, 森は「外部」に分類した。時間帯は，気温の低い5〜10時を「朝」，
製ベッドを作って働き,夜間は前庭でハンモックの様なベッドに蚊帳 をつって就寝することが多い。団扇を使用し, 暑さをしのぐために一 日 3,4 回水浴する習慣もある。 $\mathrm{T}_{\mathrm{B}}$ と $\mathrm{C}_{\mathrm{B}}$ では半外部空間がなく, $\mathrm{T}_{\mathrm{B}}$ で は昼間はテレビをみながら作業し, 朝と夕方は屋上テラス, 路地, 広 場などで作業や休賏をし， $\mathrm{C}_{\mathrm{B}}$ では夏季でも厚着で温茶を大量に领用 し, 台所で生活の大半を過ごす。 $\mathrm{T}_{\mathfrak{l}}, \mathrm{T}_{\mathfrak{n}}$ の開放的な軒下は日陰や冷 風を確保できるので,作業,休憩, 接客などに利用される。居住者は 日射や気温の変化にあわせて前庭, 半外部と内部に移動している。

\subsection{2 昼間の室温抑制}

図7(a)に外気温, 室温とグローブ温度の時刻変化を示す。平均值 は表4に示す。㡺間の室温は,室別にみると外気温より低い地域もあ る。昼間の平均室温は外気温より $4.6 \mathrm{~K}\left(\mathrm{~S}_{\mathrm{A}}\right), 0.7 \mathrm{~K}\left(\mathrm{~T}_{\mathrm{B}}\right), 0.8 \mathrm{~K}\left(\mathrm{~T}_{\mathrm{D}}\right)$,

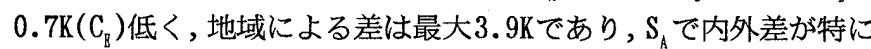
大きい。これは $S_{A}$ では土間床，土壁，日干し煉瓦や壳，開放的で大 きな平面や断面,上部の大きな開口部の効果であると思われる。また $\mathrm{T}_{\mathrm{B}}$ では煉瓦造で熱容量が大きく,外気に面する壁が一面しかなく，ま た下部階の室内に入射する日射が少ない密集市街地であること， $\mathrm{T}_{\mathrm{D}}$ では土間や石造であること， 面を削っただけの北向きの壁であることの影響が考えられる。 1 階と2 階では室温が終日 $23^{\circ} \mathrm{C}$ 付近で安定している。

\subsection{3 薪燃焼による室温上昇}

台所では開放型いろりで薪燃焼して調理を行っているため,調理時 に室温の上昇がみられる(図7(a))。表 4 に示すように台所の日平均 

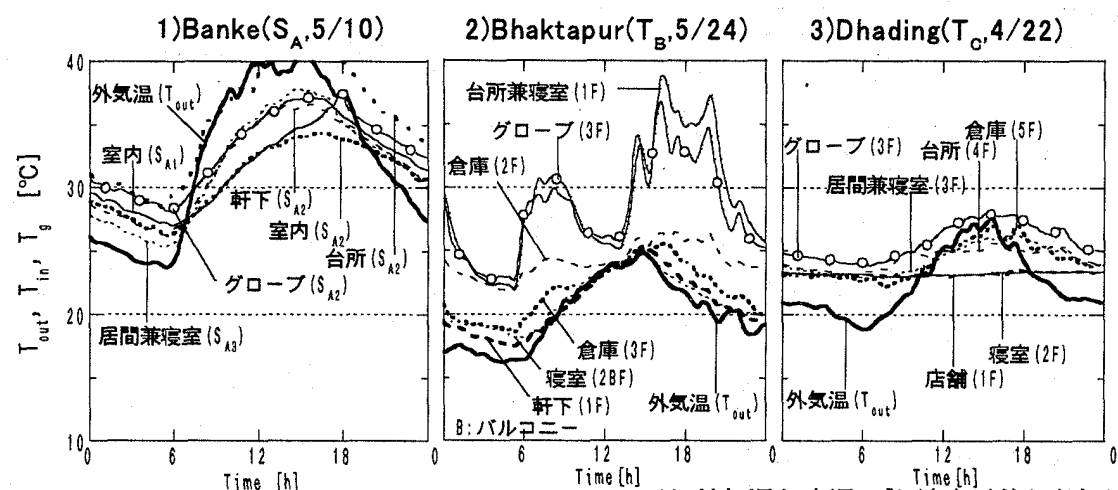

4) Kaski( $\left.T_{D}, 4 / 30\right)$

5)Solukhumbu( $\left.C_{E}, 5 / 17\right)$

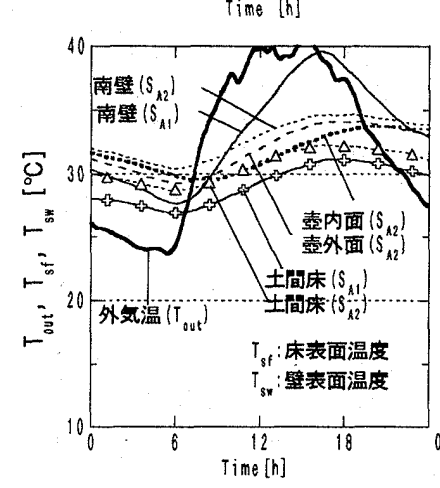

(a) 外気温と室温 [図 $(a),(d)$ (a) (e)は共通凡例]
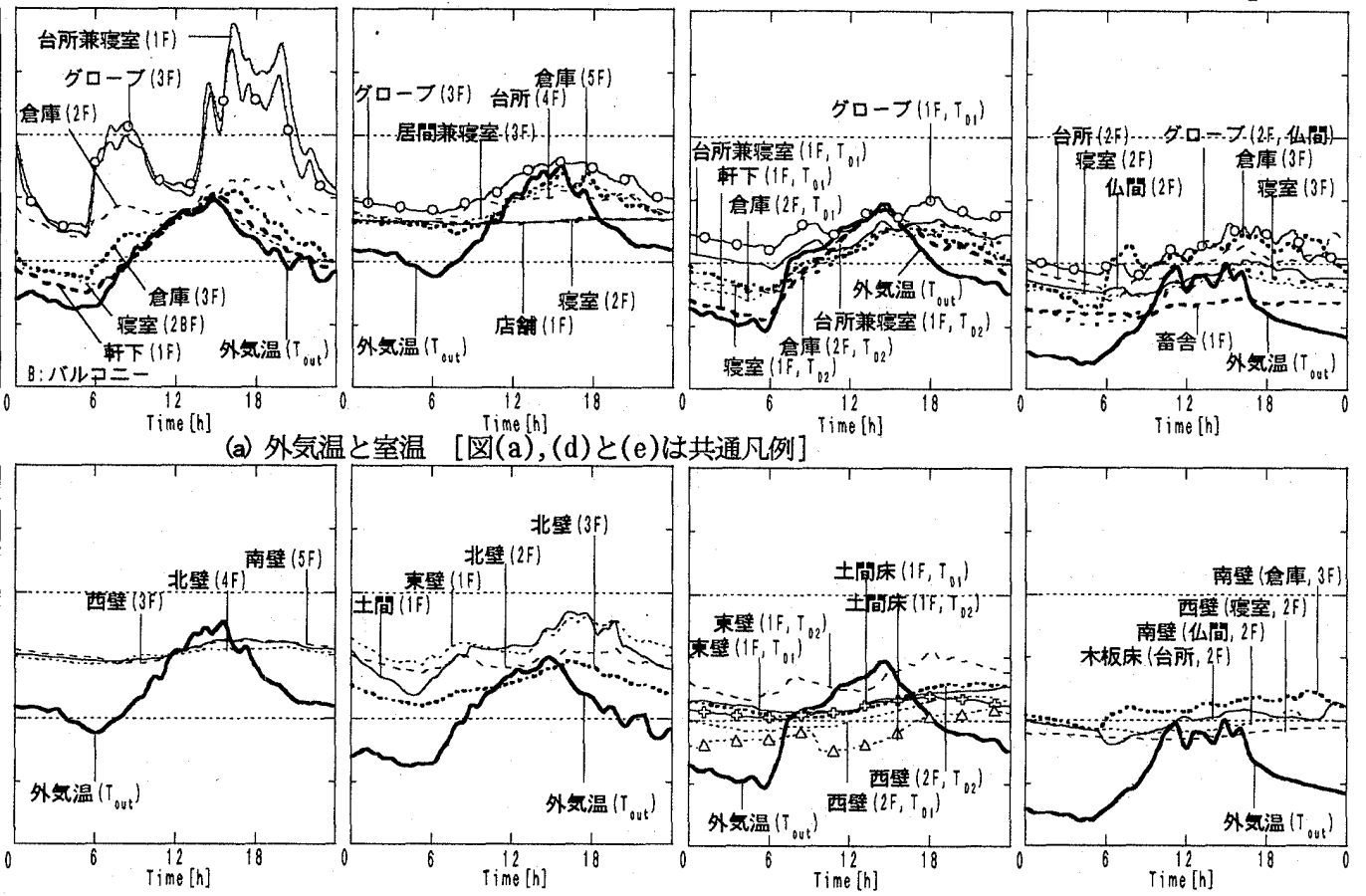

(b) 床と壁の表面温度 [図(b)と(c)は共通凡例]
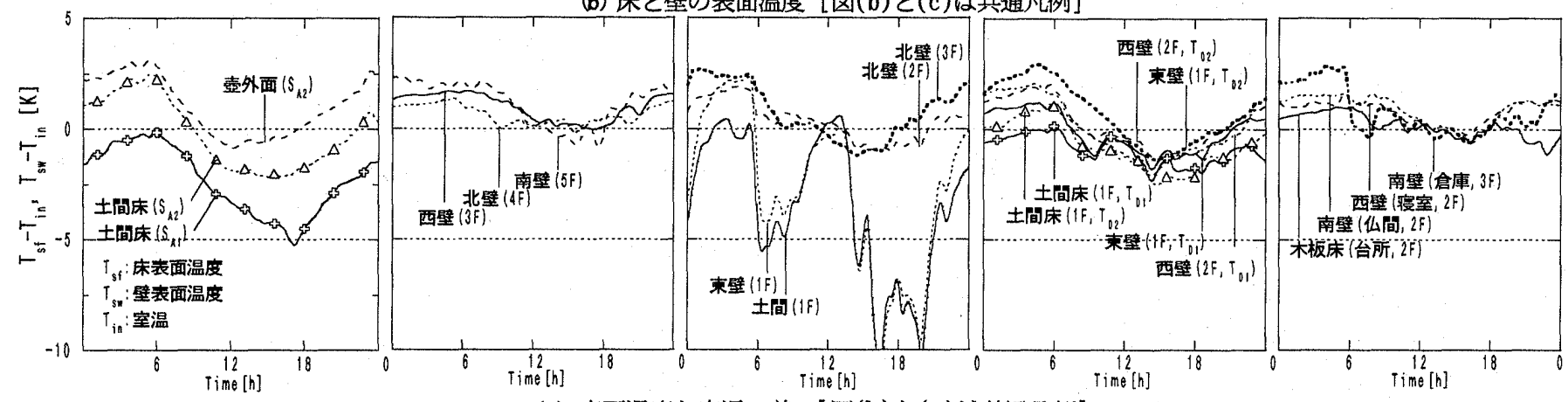

（c）表面温度と室温の差 [図(b)と(c) は共通凡例]
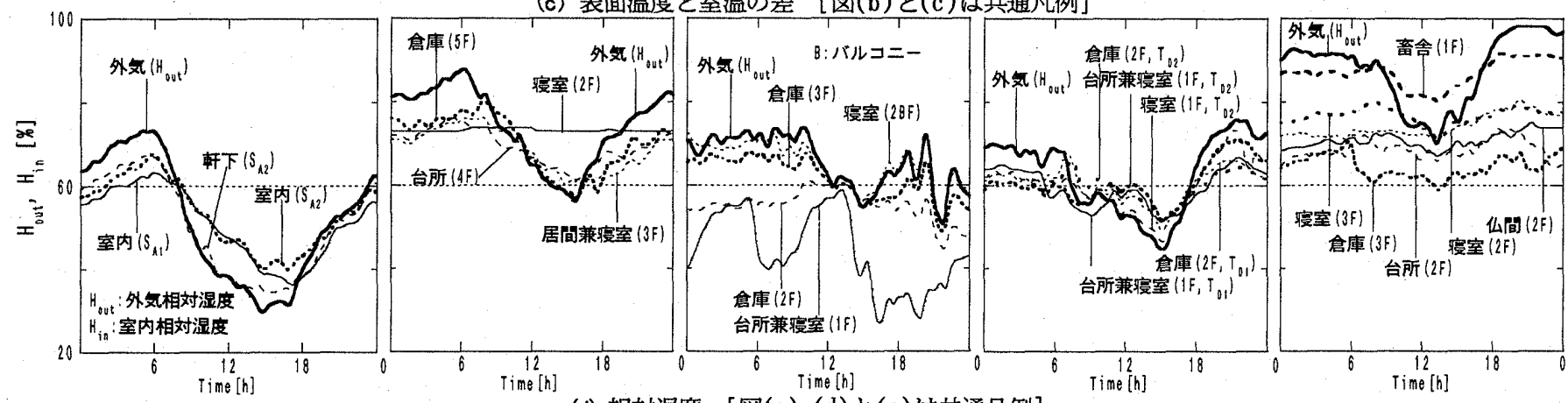

(d) 相対湿度 [図(a),(d)と(e)は共通凡例]
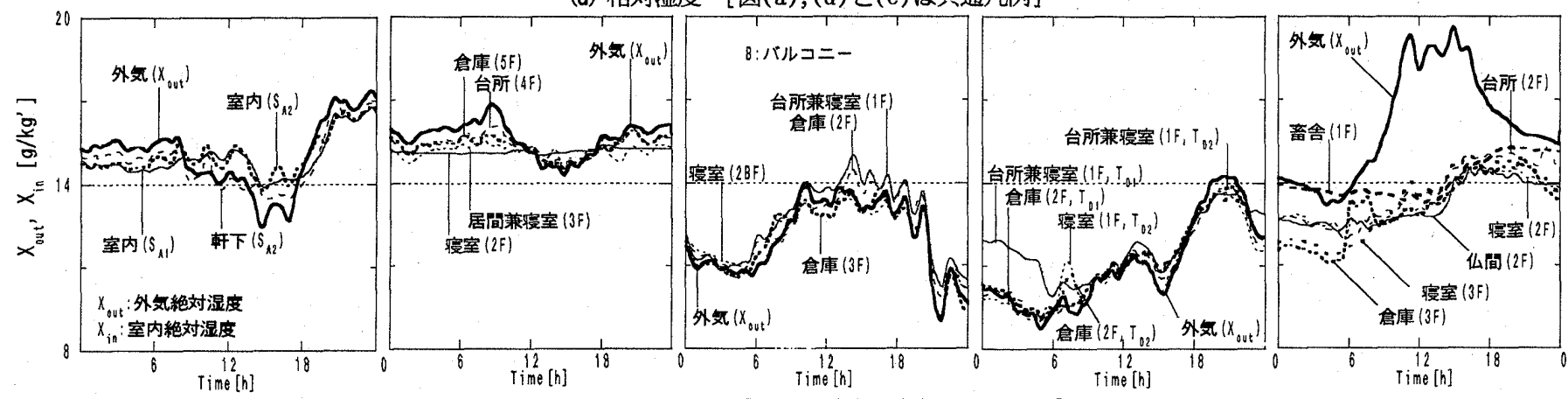

（e）絶対湿度 [図(a), (d) と(e)は共通凡例]

図7 続く 

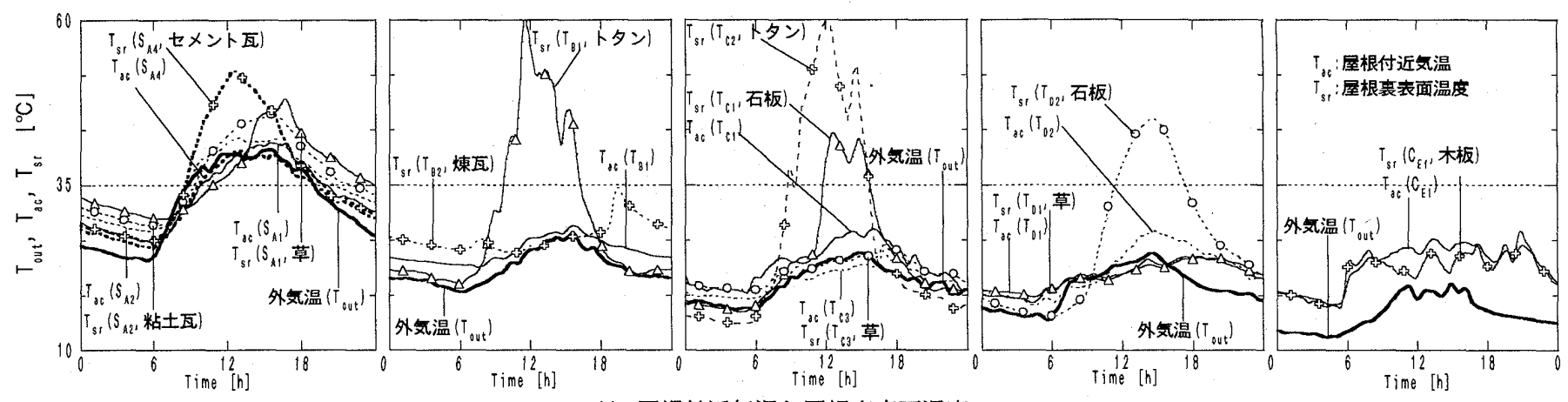

（f）屋根付近気温と屋根裏表面温度

図7 各地域の住宅における温熱環境の比較

気温は外気温より $3.8 \mathrm{~K}\left(\mathrm{~S}_{\mathrm{A}}\right), 2.0 \mathrm{~K}\left(\mathrm{~T}_{\mathrm{B}}\right), 8.7 \mathrm{~K}\left(\mathrm{~T}_{\mathrm{c}}\right), 2.1 \mathrm{~K}\left(\mathrm{~T}_{\mathrm{D}}\right), 4.2 \mathrm{~K}$ $\left(\mathrm{C}_{\mathrm{B}}\right)$ 高い。 $\mathrm{T}_{\mathrm{B}}$ で内外温度差が小さいのは空を開放しながら主に電気 ヒ一ターや灯油ストーブ(一時間程菜と籾款燃焼)を使用していたた めと思われる。T』で内外差が比較的小さいのは, 薪を節約して一回 に燃やす量が少ないためである。他の地域では，一回に燃やす薪の 量が多く,大きな室温上昇がみられる。薪からの発生熱により $\mathrm{S}_{\mathrm{A}}, \mathrm{T}_{6}$ の台所では室温が $41.9^{\circ} \mathrm{C}, 38.9^{\circ} \mathrm{C}$ まで上昇している。 $\mathrm{T}$ 。の2階の室 温は外気温より日平均で $4.1 \mathrm{~K}$ 高いのは,薪燃烓の影響が階段吹き抜 けを通じて及んだ結果であると思われる。C $\mathrm{C}_{\mathrm{g}}$ の3階の倉庫でも同様 の傾向がみられる。居住者は調理中の汗と暑さに不快を訴えていた。

\section{2 .4 日射に左右される屋根裹部屋}

屋根裹部屋は他の部屋より開放的であるにも関わらず,夜間の平 均室温は外気温より $2.2\left(\mathrm{~T}_{\mathrm{c}}\right) \sim 3.4 \mathrm{~K}\left(\mathrm{~T}_{\mathfrak{D}}, \mathrm{C}_{\mathbb{B}}\right)$ 高い(表4)。これは断熱 されていないトタンや石板の屋根から入る日射熱が床や壁に蓄えら れ，夜間に放熱されたためと考えられる。対策として，夏季の㡺間 は開口部を閉鎖し，屋根に断熱材を設けて放射熱を遮断し，夜間に 開口部を開放することが考えられる。

\section{2 .5 夏季に適した開放的な半外部空間}

半外部と外部の温度差 (半外部一外部) は, 全地域とも昼間より 夜間の方が大きく，㡺間平均は $-2.9\left(\mathrm{~S}_{\mathrm{h}}\right) \sim+0.4 \mathrm{~K}\left(\mathrm{~T}_{\mathrm{c}}\right)$ ，夜間平均は $+1.1\left(\mathrm{~T}_{\mathfrak{l}}\right) \sim+1.5 \mathrm{~K}\left(\mathrm{~T}_{\mathrm{c}}\right)$ である (表 4$) 。 \mathrm{~S}_{\mathrm{A}}, \mathrm{T}_{\mathrm{D}}$ で半外部の気温が㡺間に 外気温より低いのは,日陰になった土間や壁の冷却効果によると思 われる。半外部は午後 1,2 時間は日射が入るものの風通しが良く,昼 間の作業や夜間の就寝に利用されていた。

\subsection{6 床, 壁からの放射冷却效果}

図7(b)に外気温, 床表面温度, 壁表面温度, 図7(c)に床表面温度 と室温の差 $\left(\mathrm{T}_{\mathrm{sf}}-\mathrm{T}_{\mathrm{in}}\right)$, 壁表面温度と室温の差 $\left(\mathrm{T}_{\mathrm{sw}}-\mathrm{T}_{\mathrm{in}}\right)$ の時刻変化を 示す。平均値は表4に示す。日平均表面温度は, 室温より土間 $\mathrm{T}_{\mathrm{sf}}$ で $2.4 \mathrm{~K}\left(\mathrm{~S}_{\mathrm{k}}\right), 3.6 \mathrm{~K}\left(\mathrm{~T}_{\mathrm{c}}\right), 1.4 \mathrm{~K}\left(\mathrm{~T}_{\mathrm{D}}\right)$ ，壁 $\mathrm{T}_{\mathrm{sv}}$ で $2.8 \mathrm{~K}\left(\mathrm{~T}_{\mathrm{d}}\right), 0.2 \mathrm{~K}\left(\mathrm{~T}_{\mathrm{D}}\right)$, $0.8 \mathrm{~K}\left(\mathrm{C}_{\mathrm{B}}\right)$ 低い。 $\mathrm{T}$ では, 薪燃焼の影響で室温が上昇し，土間や壁の 表面温度と室温との差が大きい。 $\mathrm{S}_{\mathrm{A}}$ の軣と $\mathrm{T}_{\mathrm{B}}$ の棟瓦壁の表面温度 $\mathrm{T}_{\mathrm{sw}}$ は,日平均では室温よりともに約 $1 \mathrm{~K}$ 高いが,昼間には $\mathrm{T}_{\mathrm{B}}$ で $0.9 \mathrm{~K}$ 低い。土間, 石造, 棟瓦造, 壶の蓄冷効果が示された。

\subsection{7 伝統的住宅と新型住宅の比較}

伝統的住宅の $\mathrm{S}_{\mathrm{A} 1}$ (土壁)， $\mathrm{T}_{\mathrm{D} 1}$ (棈円形平面)と，新型住宅の $\mathrm{S}_{\mathrm{A} 2}$ (棟 瓦), $\mathrm{T}_{D 2}$ (矩形平面)を比較する。昼間の表面温度は, 伝統的住宅は 新型住宅より土間では $\mathrm{S}_{\mathrm{A} 1}$ で $1.6 \mathrm{~K}$ 低く, $\mathrm{T}_{\mathrm{D} 1}$ で $1.6 \mathrm{~K}$ 高く，壁では $\mathrm{S}_{\mathrm{A} 1}$ で $1.5 \mathrm{~K}$ 高く, $\mathrm{T}_{\nexists 1}$ で $1.0 \mathrm{~K}$ 低い(図7(b),(c))。これは $\mathrm{S}_{\mathrm{A} 1}$ は上部に開 口部があるため外気が土間に与える影響が小さいが, $\mathrm{S}_{\mathrm{h}}$ は空がある ため外気が土間に与える影響が大きいからである。また, $\mathrm{S}_{A 1}$ は土壁
が薄く日射の影響が大きいが, い。さらに, $\mathrm{T}_{\mathrm{D} 1}$ の方が薪の消費量が多く, 土間表面温度が $\mathrm{T}_{\mathrm{D} 2}$ より 高いが， $\mathrm{T}_{D 1}$ の方が開口部が小さく壁表面温度は低い。新型住宅で 室温を下げるには， $\mathrm{S}_{\mathrm{A} 2}$ で上部に開口部を設置し， $\mathrm{T}_{D 2}$ で開口部を気 密化するべきであろう。

\subsection{8 土間, 石造, 棟瓦造の調湿作用}

図7(d)に外部と室内の相対湿度, 図7(e)に外部と室内の絶対湿 度の時刻変化を示す。図8に内外絶対湿度の平均值, 最小值と最大 値を示す。平均值は表4に示す。各地域の室内の日平均相対湿度は 外部より低く, $\mathrm{T}_{\mathrm{c}}$ と $\mathrm{C}_{\mathrm{B}}$ では差が大きく最大 $23 \%$ にぶ。 $\mathrm{T}_{\mathrm{t}}$ の台所 では薪燃焼によって室温が上昇し, $\mathrm{C}_{\mathrm{g}}$ では空閉鎖の習慣によって室 内空気が乾燥することに関係していると思われる。他の地域は開放 的であり,内外の差は僅かであつた。また，各地域の室内の日平均 絶対湿度は外部より $0.2 \mathrm{~g} / \mathrm{kg}^{\prime}$ 低い場合もあるがほとんどで室内の ほうが高く, 最大 $0.8 \mathrm{~g} / \mathrm{kg}^{\prime}$ 高い。各地域とも台所の湿度が高いの は,調理で発生した水蒸気のためである。室内の絶対湿度の日較差 は最も小さい部屋で外部より $2.0\left(\mathrm{~S}_{\mathrm{A}}\right), 2.2\left(\mathrm{~T}_{\mathrm{B}}\right), 1.8\left(\mathrm{~T}_{\triangleright}\right), 4.1 \mathrm{~g} /$ $\mathrm{kg}^{\prime}\left(\mathrm{C}_{\mathrm{g}}\right)$ 小さく(図8), 石造, 棟瓦造, 土壁の調湿作用が示された。

\section{2 .9 屋根の熱的性能}

図7(f)に外気温, 屋根裏付近気温 $\left(\mathrm{T}_{\mathrm{ac}}\right)$, 屋根裏表面温度 $\left(\mathrm{T}_{\mathrm{sr}}\right)$ の 時刻変化, 図 9 に外気温, 表面温度の平均值, 最小値と最大値を示 す。表 5 に屋根裏付近気温と屋根裏表面温度の平均値を示す。

各地域の屋根裏付近気温は外気温より $0.4\left(\mathrm{~S}_{\mathrm{A}}\right) \sim 6.6 \mathrm{~K}\left(\mathrm{C}_{\mathrm{B}}\right)$ 高い。 また, 屋根裏表面温度は外気温より $1.8\left(\mathrm{~T}_{c}, \mathrm{~T}_{\mathrm{D}}\right) \sim 7.6 \mathrm{~K}\left(\mathrm{~T}_{\mathrm{B}}\right)$ 高い。 屋根裏表面温度は, 屋根裏付近気温より高い。

各地域の草莫きの屋根裏表面温度は最大 $48.1^{\circ} \mathrm{C}\left(\mathrm{S}_{\AA}\right), 26.0^{\circ} \mathrm{C}$ $\left(\mathrm{T}_{\mathrm{c}}\right), 24.1^{\circ} \mathrm{C}\left(\mathrm{T}_{\mathrm{D}}\right)$ で, 日較差は $18.1 \mathrm{~K}\left(\mathrm{~S}_{\mathrm{A}}\right), 7.0 \mathrm{~K}\left(\mathrm{~T}_{\mathrm{c}}\right), 6.0 \mathrm{~K}\left(\mathrm{~T}_{\mathrm{D}}\right)$ で あり,亜熱帯では表面温度も日較差もともに大きい。草莫きの厚さ が亜熱帯で $20 \mathrm{~cm}$, 温帯で60cmであるという違いによると思われる。 また, $\mathrm{T}_{\mathrm{B}}$ の棟瓦張りと $\mathrm{C}_{\mathrm{B}}$ の木板荤きの表面温度は最大 $28^{\circ} \mathrm{C}$ と 26.9 ${ }^{\circ} \mathrm{C}$, 日較差は $3.4 \mathrm{~K}$ と $9.9 \mathrm{~K}$ であり, 熱的性能は草咠きに近く, 煉瓦 張りと木板の断熱効果があつた。伝統的な建材である草咠き,煉瓦 張り，木板咠きで日射の影響が少なく，断熱性の高さが示された。

$\mathrm{S}_{\mathrm{A}}$ の粘土瓦咠きの屋根裹表面温度は最大 $45.7^{\circ} \mathrm{C}$ で，日較差は $16.8 \mathrm{~K}$ である。粘土瓦咠きには断熱が施されておらず, 屋根裏付近 に熱気が溜まるためと思われる。また，石板葛きの屋根裏表面温度 は最大 $42.9^{\circ} \mathrm{C}\left(\mathrm{T}_{\mathrm{c}}\right), 44.9^{\circ} \mathrm{C}\left(\mathrm{T}_{\mathrm{D}}\right)$, 日較差は $27.1 \mathrm{~K}\left(\mathrm{~T}_{\mathrm{c}}\right), 29.8 \mathrm{~K}\left(\mathrm{~T}_{\mathrm{D}}\right)$ であり,表面温度も日較差もともに大きい。これらの石板咠きの温 度上昇は同じ地域の草咠きより大きい。 $\mathrm{T}_{\mathrm{c}}$ の石板は約 $20 \mathrm{~cm} \times 20 \mathrm{~cm}$ $\times 2 \mathrm{~cm}$ と薄型で小さく, 石板の間に多くの腺間があるのに対して, 


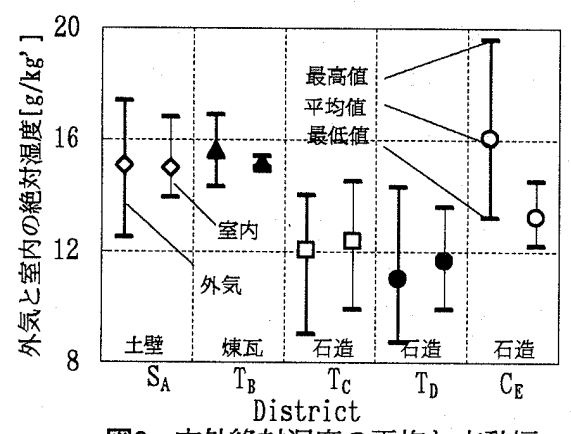

図8 内外絶刘湿度の平均と変動幅
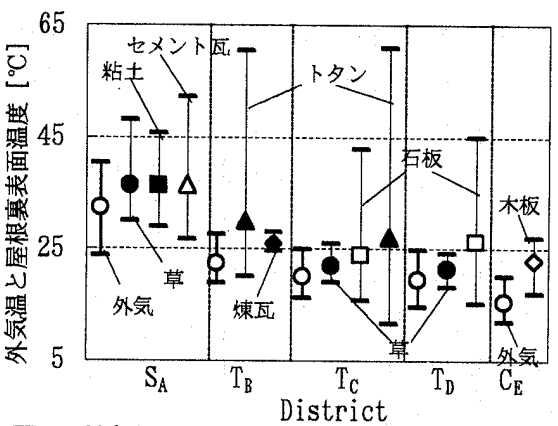

表5 各地の屋根裏付近気温と屋根裏表面温度

\begin{tabular}{|c|c|c|c|c|c|c|}
\hline 根材 & 地域 & $\mathrm{Tac}_{\mathrm{a}-\mathrm{T}_{\mathrm{ou}}}$ & $T_{\text {sr }}-T_{\text {out }}$ & 局屋根身 & and & $\mathrm{sr})\left[{ }^{\circ} \mathrm{C}\right]$ \\
\hline & & [K] & {$[\mathrm{K}]$} & 最高 & & \\
\hline & $S_{\Lambda}$ & 1.2 & 4.0 & 48.1 & 30.0 & \\
\hline & $\mathrm{T}_{\mathrm{G}}$ & 0.5 & 1.8 & 26.0 & 19.0 & 7.0 \\
\hline & $T_{D}$ & 1.8 & 1.8 & 24.1 & 18.1 & 6.0 \\
\hline & $T_{B}$ & & 3.6 & 28.0 & 24.6 & 3.4 \\
\hline & $C_{B}$ & 6.6 & 7.4 & 26.9 & 17.0 & 9.9 \\
\hline 点土瓦 & $S_{A}$ & 2.7 & 4.0 & 45.7 & 28.9 & 16.8 \\
\hline 石板 & $T_{6}$ & 2.9 & 3.7 & 42.9 & 15.8 & 27.1 \\
\hline & $I_{D}$ & 2.5 & 6.8 & 44.9 & 15.1 & \\
\hline 下多 & $T_{B}$ & 2.7 & 7.6 & 60.4 & 20.0 & 40.4 \\
\hline & $\frac{T_{C}}{C}$ & - & 7.0 & 60.9 & 11.6 & 49.3 \\
\hline & $\frac{S_{A}}{4(2)}$ & 0.4 & 4.1 & $\frac{52.2}{10.1}$ & 40.0 & 25.6 \\
\hline
\end{tabular}

図9 外気温と屋根裏表面温度の平均と変動幅

$\mathrm{T}_{\triangleright}$ の石板は約 $80 \mathrm{~cm} \times 50 \mathrm{~cm} \times 5 \mathrm{~cm}$ と厚型で大きく，石板の間にほと んど陌間がないことによる違いであると思われる。即ち, $\mathrm{T}_{\mathrm{n}}$ の屋根 はT の屋根より屋根暠付近に熱気が溜まりやすく表面温度上昇が大 きいといえる。伝統的な建材である粘土瓦・石板㗲きは日射の影響 を受けやすく,断熱性の低さが示された。

トタン革きの屋根裏表面温度は最大 $60.4^{\circ} \mathrm{C}\left(\mathrm{T}_{\mathrm{B}}\right), 60.9^{\circ} \mathrm{C}\left(\mathrm{T}_{\mathrm{c}}\right)$, 日較差は $40.4 \mathrm{~K}\left(\mathrm{~T}_{\mathrm{B}}\right), 49.3 \mathrm{~K}\left(\mathrm{~T}_{\mathrm{c}}\right)$ であり, トタン咠きは表面温度も 日較差もともに大きい。また， $\mathrm{S}_{\mathrm{A}}$ のセメント瓦咠きの屋根董表面温 度は最大 $52.2^{\circ} \mathrm{C}$, 日較差は $25.6 \mathrm{~K}$ であり，表面温度も日較差もとも に大きい。トタン・セメント瓦咠きは日射により温度が上昇し，断 熱されていないため室内への影響がみられた。工業建材であるト夕 ン・セメント瓦咠きに断熱の不備が示された。

\subsubsection{0 屋根材の放射冷却効果}

昼間の屋根裏表面温度は外気温より草革きで最大 $4.4 \mathrm{~K}\left(\mathrm{~S}_{\mathrm{A}}\right), 0.7 \mathrm{~K}$ $\left(\mathrm{T}_{\mathrm{c}}\right), 1.9 \mathrm{~K}\left(\mathrm{~T}_{\mathrm{D}}\right)$, 粘土瓦革き，セメント瓦莫き，棟瓦張り，石板咠 きでそれぞ最大 $1.8 \mathrm{~K}\left(\mathrm{~S}_{\mathrm{A}}\right), 1.6 \mathrm{~K}\left(\mathrm{~S}_{\mathrm{A}}\right), 1.0 \mathrm{~K}\left(\mathrm{~T}_{\mathrm{B}}\right), 3.9 \mathrm{~K}\left(\mathrm{~T}_{\mathrm{D}}\right)$ 低い。 $\mathrm{T}$ では草莫きの屋根裏の平均表面温度は外気温と等しく, 㡺間の温 度抑制に効果があった。夜間の屋根裏の最低表面温度は外気温に比 べて $\mathrm{T}_{\mathrm{c}}$ の石板蕞きで $1.3 \mathrm{~K}$ ，トタン革きで $5.4 \mathrm{~K}$ 低い。 $\mathrm{T}_{\mathrm{c}}$ の屋根裏の 夜間平均表面温度は, 石板㯰きでは外気温と等しく, ト夕ン咠きで は外気温より $2.5 \mathrm{~K}$ 低く, 夜間の温度低下に効果があった。草蕞き, 棟瓦張り, 石板咠き $\left(\mathrm{T}_{\mathrm{p}}\right)$ は昼間に, 石板咠き $\left(\mathrm{T}_{\mathrm{l}}\right)$, ト夕ン咠きは夜 間に放射冷却効果がみられた。

\subsubsection{1海抜による内外温度差の差異}

表6に全実測住宅の内外温度差の範囲と地域ごとの平均值を示す s)。半外部と外部の温度差は除いた。各地域の海抜と日平均内外温度 差の関係は, 海抜の低い地域 $\left(\mathrm{S}_{\mathrm{h}}, 150 \mathrm{~m}\right)$ では小さく $(-0.3 \mathrm{~K})$, 海抜の 高い地域 $\left(\mathrm{C}_{\mathrm{B}}, 2600 \mathrm{~m}\right)$ では大きい $(2.3 \mathrm{~K})$ 。平均内外温度差と海抜の相 関は高く $(r=0.85)$, 低地では開放系住居, 高地では閉鎖系住居であ

表6 ネパールと日本・中国の伝統的住宅の内外温度差の比較

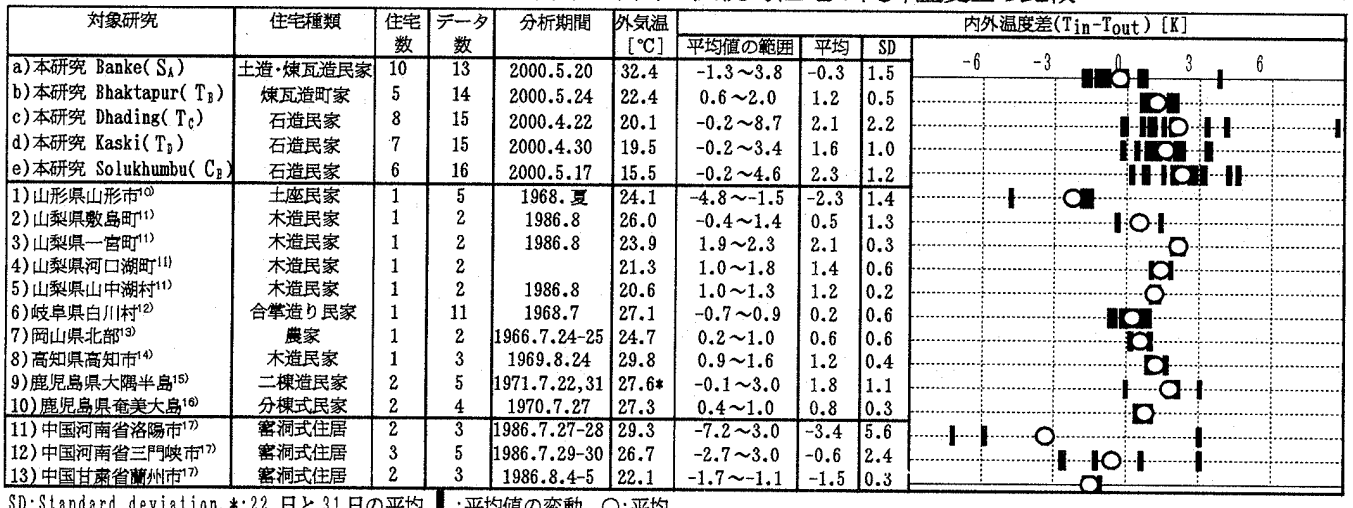

$S D:$ Standard deviation, $*: 22$ 日と 31 日の平均, $\mid$ :平均值の変動, $O:$ 平均
ることを示している。T薪燃焼による台所の過剩な室温上昇を除く と，相関は更に高くなる $(r=0.96)$ 。

\section{3 日本や中国の伝統的住宅との内外温度差の比較}

表 6 にネパールでの本実測と日本 ${ }^{(0) ~}{ }^{16)}$ や中国(1) の夏季の既往の 調查における内外温度差との比較を示す。本来であれば,効果が期待 できる㡺間の時間帯の值を比較するべきであるが,日本や中国の既往 の文献には日平均や月平均値しか示されていない。このため,本害測 の日平均值をこれらの文献の平均值と比較する。

表中の「デー夕数」の列はその地域における測定点数をあらわす。 ネパール各地域の伝統的住宅における内外温度差(室温一外気温)の 日平均值の範囲を表の「平均值の範囲」の列に, それぞれの地域の全 測定点で平均した值を表の「平均」の列に示す。測定点には台所の值 も含めた。日本や中国の文献も本研究の整理方法に一致させて示す。 表によると,ネパールの伝統的住宅における夏季の日平均内外温度差 は，-0.3〜2.3Kの範囲にある。

既往の調查と比較すると,内外温度差が本実測より小さいのは,1) 山形市土座民家と，11） 13) 中国窑洞である。1)は土座の，11） 13)は地温の効果によると推測される。これらを除くと, 日本の夏季 における内外温度差の範囲は $0.2 \sim 2.1 \mathrm{~K}$ であり, 本実測の $-0.3 \sim$ $2.3 \mathrm{~K}$ の範囲とほぼ同じである。

冬季については, 既報 ${ }^{1)}$ においてネパール（地域 $\mathrm{T}$ 。 み）の実測 值と既往調查における日本の内外温度差を比較したが,両者はほほ同 程度で $1.5 \sim 3.0 \mathrm{~K}$ の範囲にあった。すなわち，内外温度差の日平均 值でみれば,夏季冬李ともにネパールと日本の伝統的住宅の熱的性能 にはあまり差がない。この結果は必ずしも建物の熱的な構造が同じで あることを意味しない。今後シミュレーションなどにより検討する予 定であるが,各地域の伝統的住宅の性能に差がないとすれば,伝統的 住宅を考えるうえで注目に值する結果である。ただし㡺間の時間帯に 限定すれば,既述のようにネパールにおける本実測での内外温度差の 㡺間の平均値は,最も効果のあ る場合で $-4.6 \mathrm{~K}\left(\mathrm{~S}_{\mathrm{A} 2}\right.$ の部屋, 表 4 参照) である。

冬季と夏季を比較する。既往 研究のうち山形県土座民家と中 国窑洞式住居を除いた 9 地域 (冬季は 5 地域), およびネパー ルの 5 地域 (冬季は 1 地域) に おける地域ごとの平均值（表 6 では「平均」の列）を日本とネ パールを合わせて冬季と夏季で それそれ平均すると，冬季は 
$2.2 K^{1)}$ ，夏季は $1.2 \mathrm{~K}$ である。冬季の方が $1 \mathrm{~K}$ 大きいのは，冬季は開 口部を閉鎖して内外温度差を大きくするよう工夫し,冬と夏で住宅 の開閉状況を変えて温熱環境を調節した結果であると考えられる。

\section{5. 結論}

ネパールの5つの地域において夏季の住宅温熱環境の実測を行い， 室内外温熱環境と土間·壁·屋根などの表面温度を比較した結果, 以 下のことが明らかになった。対象とした地域は亜熱帯のBanke $\left(\mathrm{S}_{\mathrm{A}}\right)$, 温帯のBhaktapur $\left(\mathrm{T}_{B}\right)$, Dhading $\left(\mathrm{T}_{\uparrow}\right)$, Kaski $\left(\mathrm{T}_{D}\right)$ と冷帯の Solukhumbu 郡 $\left(\mathrm{C}_{\mathrm{B}}\right)$ である。

1) 居住者の滞在場所に関する調查から, 居住者が内部, 半外部, 前 庭を時間的に移動して居住温熱環境を緩和している実態が示され

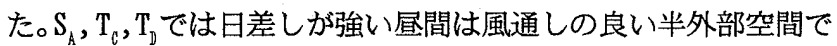
過ごし，夜間は低温と冷風を求めて $\mathrm{S}_{\mathrm{A}}$ では前庭で， $\mathrm{T}_{\mathfrak{l}}, \mathrm{T}_{\mathrm{D}}$ では半 外部で就寝する。

2 ) 各地域で㡺間の平均室温は外気温より $\mathrm{S}_{\AA}$ で $4.6 \mathrm{~K}, \mathrm{~T}_{\mathrm{B}}, \mathrm{T}_{\text {D }}$ で $0.7 \mathrm{~K}, 0.8 \mathrm{~K}$ 低く, 亜熱帯で内外差が大きい。亜熱帯の開放的な土 間の効果が示された。T密集市街地の日射が殆ど当たらない下部 階では, 昼夜の室温は $23^{\circ} \mathrm{C}$ 付近で安定していた。開放型いろりで 多量の薪を燃焼した $S_{\AA}, T_{c}$ では, 台所の気温が最高 $41.9^{\circ} \mathrm{C}, 38.9$ ${ }^{\circ} \mathrm{C}$ ま゙上昇していた。台所付近の過熱は処理する必要がある。

3)開放的な半外部空間では気温温や風速が㡺夜とも外部に近く,昼 間の作業や夜間の就寝に利用されていた。

4)土間床や壁からの放射冷却効果がみられた。日平均表面温度は,室 温より土間では $\mathrm{S}_{\mathrm{A}}$ で $2.4 \mathrm{~K}, \mathrm{~T}_{\mathrm{c}}, \mathrm{T}_{\mathrm{D}}$ で $3.6 \mathrm{~K}, 1.4 \mathrm{~K}$ 低く, 壁では $\mathrm{T}_{\mathrm{c}}, \mathrm{T}_{\mathrm{D}}$ で $2.8 \mathrm{~K}, 0.2 \mathrm{~K}, \mathrm{C}_{\mathrm{B}}$ で $0.8 \mathrm{~K}$ 低かった。 $\mathrm{S}_{\mathrm{A}}$ の壹と $\mathrm{T}_{\mathrm{B}}$ の煉瓦壁の表 面温度は昼間で室温より最大で $0.8 \mathrm{~K}, 0.9 \mathrm{~K}$ 低かった。

5)伝統的住宅と新型住宅を比較すると,㡺間の表面温度は伝統的住 宅のほうが $\mathrm{S}_{\mathrm{A} 1}$ の土間で $1.6 \mathrm{~K}, \mathrm{~T}_{D 1}$ の壁で $1.0 \mathrm{~K}$ 低い。伝統的住宅 の原理を応用して室温を下げるために,新型住宅のS $\mathrm{S}_{\mathrm{A}}$ では上部に 開口部を設置し， $\mathrm{T}_{\mathrm{D} 2}$ では開口部を気密化すべきであろう。

6)室内の絶対湿度の日較差が外部より $1.8\left(\mathrm{~T}_{\mathrm{D}}\right) \sim 4.1 \mathrm{~g} / \mathrm{kg}^{\prime}\left(\mathrm{C}_{\mathrm{B}}\right)$ 小さ く，土間，土壁造，棟瓦造，石造の調湿作用が示された。

7) $\mathrm{S}_{\mathrm{A}}$ の棟瓦張り, $\mathrm{T}_{\mathrm{C}}, \mathrm{T}_{\mathrm{D}}$ の草革き, $\mathrm{C}_{\mathrm{B}}$ の木板龩きの屋根裏表面温度の 日較差は $3.4 \sim 9.9 \mathrm{~K}$ と小さく, 断熱性能が高い。一方, 伝統的な 建材の $\mathrm{S}_{\hbar}$ の草咠き, 粘土瓦楞き, $\mathrm{T}_{c} ; \mathrm{T}_{\mathrm{D}}$ の石板咠きや, 工業建材 の $\mathrm{S}_{\mathrm{A}}$ のセメント瓦咠き, $\mathrm{T}_{\mathrm{B}}, \mathrm{T}_{\mathrm{c}}$ のトタン蕞きでは, 屋根裏表面温 度は最高42.9〜 $60.9^{\circ} \mathrm{C}$ まで上昇がみられ, 日較差も $16.8 \sim 49.3 \mathrm{~K}$ と大きく，断熱性能が低く，室温上昇への影響が示された。

8)屋根裏表面温度は, 外気温より昼間の草葛き, 棟瓦張り, 石板直 き $\left(\mathrm{T}_{\mathrm{D}}\right)$, 粘土瓦當きとセメント瓦當きでは最大 $0.7 \sim 4.4 \mathrm{~K}$ 低く， 夜間の石板咠き $\left(\mathrm{T}_{\mathrm{c}}\right)$ とトタン咠きでは最大 $1.3 \mathrm{~K}$ と $5.4 \mathrm{~K}$ 低く, 屋 根の放射冷却の効果が示された。

$9)$ 日平均内外温度差は海抜の低い地域 $\left(\mathrm{S}_{\mathrm{A}}, 150 \mathrm{~m}\right)$ では小さく $(-0.3 \mathrm{~K})$, 海抜の高い地域 $\left(\mathrm{C}_{\mathrm{g}}, 2600 \mathrm{~m}\right)$ では大きい(2.3K)。低地では開放系住 居,高地では閉鎖系住居であることが示された。

10)日本の伝統的住宅における夏季の室内外温度差は,内外温度差の 日平均值を各地域で平均した值でみた場合,ネパールにおける実 測結果の-0.3〜2.3Kの範囲内にある。冬季も日本とネパールで ほぼ同じ範囲にあったことから,内外温度差の日平均でみれば日
本とネパールの伝統的住宅の熱的性能にあまり差はないといえる。 11)ネパールと日本の伝統的住宅における内外温度差は夏季 $(1.2 \mathrm{~K}$ 炔 冬季 $(2.2 \mathrm{~K})$ より $1 \mathrm{~K}$ 小さい。夏季に開放的, 冬季に閉鎖的という生 活習慣に関連があると考えられる。

謝辞

四面の実測に芝浦工業大学・畑研究室の方々に多大なこ協力を頂いた。また本研究 は, 平成 13 年度笹川科学研究助成を受けた。記して謝意を表す。

本論文に関する既発表論文

a) H.B.リジャル,吉田治典,梅宮典子:ネパールの伝統的往宅における夏季の温熱 環境調查と評価, 日本建築学会近畿支部研究報告集(環境系), 第41号,pp.277$280,2001.6$.

b) H.B.リジャル,吉田治典,梅宮典子:ネパールの伝統的住宅における夏季の温熱 環境の地域差, 日本建築学会大会学術講演梗概集, D-1, pp1061-1062, 2001.9。 注

注1)各地域の伝統的住宅は周辺加得られる自然の建材を利用し，その地域の伝統 的構法を活かして村人自身が建て,各地域の伝統文化が反映される。また,田 畑や家畜による自給自足の生活であるため,工業建材の購入が困難で,新しい 構法が導入されることも殆どない。同一地域には類似した住宅が広範囲に建つ ことには,こうした理由があると思われる。

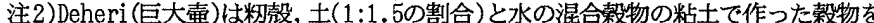
保存する巨大壳である。色々なサイズの壳を適切に配置して,台所,寝室,祈り部 屋などを作る。

注 3 ) 壁は厚さ約 $15 \mathrm{~cm}$ であり，木の格子で骨組みを作り，土，牛や水牛粪，籶 殸 $(2: 1: 0.5$ の割合) と水の混合物で作ったモルタルを内外から塗って仕上 げる。土壁は雨には弱く，毎年乾季に作り直す。

注4)石造壁は厚さ約 $50 \mathrm{~cm}$ であり,厚さ的 $20 \mathrm{~cm}$ の石を厚さ約 $5 \mathrm{~cm}$ の粘土で接合して,内 外から粘土を塗って仕上げる。

\section{参考文献}

1）リジャル ホムバハドゥル,吉田治典,梅宮典子:ネパール山岳地帯の伝 統的住宅における冬季の温熱環境調査, 日本建築学会計画系論文集,第546 号, pp. 37-44, 2001.8.

2) Ram Kumar Panday: Development Disorders in the Himalayan Heights Challenges and Strategies for Environment and Development Altitude Geography, Ratna Pustak Bhandar, Baghbazar, Kathmandu Nepal, pp. 53,290, 1995.

3) H.M.G. of Nepal: Climatological Records of Nepal 1987-1990,19911994,1995-1996, Ministry of Science and Technology Department of Hydrology and Meteorology, Kathmandu, 1995.6, 1997.5,1999.6.

4）曹香伊，梶原圭介，小畑瓦平，畑䧔一，H.B.リジャル:南西部夕ライ平原 に居住するタルー族の事例 ネパールにおける伝統的住居の空間構成に関す る研究その 3 , 日本建築学会大会学術講演梗概集, E-2, pp.491-492, 2001.9 .

5）小畑瓦平, 㭺原圭介, 曹香伊, 㚼聡一,H.B.リジャル:カトマンズ盈地バク タプルに居住するネワール族の事例 ネパールにおける伝統的住居の空間楧 成に関する研究 その 2 , 日本建築学会大会学術講演梗概集, E-2, pp.489$490,2001.9$.

6）芝浦工業大学・畑研究室，H.B.リジャル，栗原宏光：特集 ネパールヒン ドウー教が山中に描く集落世界, 住宅建築, pp.30-73，1997.3.

7）佐々木高明(共著): 住まいの原型I, 鹿島出版会, pp.277-289, 1971.10.

8）原広司編:インド・ネパールの集落の構造論的考察, SD別冊10号,pp.136$137,1978$.

9）楃原圭介，小畑瓦平，曹香伊，畑榆一，H.B．リジャル: 北部山岳地に居住 するセエルパ族の事例 ネパールにおける伝統的住居の空間構成に関する研 究 その1, 日本建築学会大会学術講演梗概集, E- $2, p p .487-488,2001.9$.

10）市川啓子, 金子幸子, 梁瀨度子, 花岡利昌: 民家の微気候学的研究 第 5 報 山形県の土座民家の室内気候について, 家政学研究,Vol.17 No.1,pp.91$96,1970.6$.

11 ) 宮野則彦, 浅見雅子, 宮野秋彦: 寝室及び便所の温湿度变化から見た居住環 境の考察 山梨県下の伝統的木造民家を対象として, 日生気誌, 27(2), pp. $57-70,1990$.

12) 梁濑度子, 今村史子, 市川啓子, 花岡利昌: 民家の微気候学的研究 第 4 報 岐皁県白川村合掌造り民家の室内気候について，家政学研究，Vol.16 No.1.2, pp.64-73, 1969.12.

13 ) 高須謙一:農家の夏季気候の 1 観測例, ハウスクリマ研究ノート, 京都府立 大学，第 1 昂, pp.32-33，1969.9.

14）赤松照子, 名城美耶子, 近藤百合子, 梁瀬度子, 花岡利昌: 民家の微気候学 的研究第11報温暖地区(四国南岸)における鉄筋コンクリート造・ブロッ ク造および木造住宅の夏季の居住気候の一観測, 家政学研究, Vol.19 No. 2 , pp.129-138, 1972.12

15）忍山真砂子, 古山佳世, 市川啓子, 梁瀬度子, 花岡利昌: 鹿児島県大隅半島 における二棟造民家の室内気候について, 家政学研究, Vol.20 No.2, pp. $161-171,1973.12$

16) 森田幸子, 市川敬子, 梁瀨度子, 花岡利昌:民家の微気候学的研究 第 9 報 鹿児島県奄美大島における分棟式民家の室内気候ならびにコンクリート住宅 のそれとの比較について, 家政学研究, Vol.19 No.1 ,pp.36-45, 1972.6.

17）稲枼一八,宮野秋彦: 中国黄河流域蜜洞式住居の内部㻴境に関する調查 第 5 報 夏季の窑洞内温熱環境, 日本建築学会東海支部研究報告, pp.245$248,1987.2$.

（2001年10月10日原稿受理，2002年 4 月16日採用決定 